\title{
Geochemical and petrological diversity of mafic magmas from Mount St. Helens
}

\author{
Maren Wanke ${ }^{1}$ - $\cdot$ Michael A. Clynne ${ }^{2} \cdot$ Albrecht von Quadt $^{1} \cdot$ Torsten W. Vennemann $^{3} \cdot$ Olivier Bachmann $^{1}$
}

Received: 25 April 2018 / Accepted: 24 December 2018

(c) Springer-Verlag GmbH Germany, part of Springer Nature 2019

\begin{abstract}
Quaternary eruptive products in the Cascade arc include a variety of different basalt types. At Mount St. Helens (MSH), the most active volcano in the Cascades throughout the last $35 \mathrm{ka}$, three different mafic endmembers erupted at the end of the Castle Creek period (1900-1700 years B.P.): (1) high-field strength element (HFSE)-rich basalt enriched in K, Ti, P, and incompatible trace elements; (2) low-K olivine tholeiite (LKOT) with lower amounts of incompatible trace elements; and (3) calc-alkaline (arc-type) basaltic andesite with a typical subduction signature, i.e., enrichment in fluid-mobile large ion lithophile elements (LILE) relative to immobile high-field strength elements (HFSE). Each type has compositions projecting backwards to more primitive endmembers in the Cascades. Single units encompassing basaltic-to-basaltic andesitic compositions with intermediate trace-element abundances form two almost continuous trends towards basaltic andesite. These trends are interpreted to result from assimilation of pre-existing, more evolved, calc-alkaline material (and in one case mixing of different mafic magma types) during migration of the magmas through the crust. Most of the erupted basalts are porphyritic $(10-30 \%)$ with an assemblage dominated by olivine and plagioclase and show disequilibrium textures preventing detailed reconstruction of mantle melting processes. Although typical hydrous arc basalt produced by flux melting in the mantle is absent in the eruptive products of MSH, arc-type basaltic andesite suggests its presence at depth. LKOT magmas are interpreted as decompression melts from the upper mantle, whereas HFSE-rich basalts are likely derived from the water-poor periphery of the main flux melting regime, potentially tapping a trace-element-enriched source. Primitive spinel compositions and whole-rock trace-element variations indicate at least two distinct, relatively fertile lherzolite sources for these two basalt types. Weak crustal zones associated with an old fracture system beneath MSH likely provide conduits for fast and isolated ascent of distinct batches of magma, bypassing the lower crustal mush zone. The eruption of the basalts through the upper crustal magma system and main edifice is consistent with an offset plumbing system suggested by geophysical data.
\end{abstract}

Keywords Mount St. Helens · Basalt · Trace elements $\cdot$ Chromian spinel $\cdot$ Olivine $\cdot$ Arc magmatism

Communicated by Othmar Müntener.

Electronic supplementary material The online version of this article (https://doi.org/10.1007/s00410-018-1544-4) contains supplementary material, which is available to authorized users.

Maren Wanke

maren.wanke@erdw.ethz.ch

1 Department of Earth Sciences, Institute of Geochemistry and Petrology, ETH Zürich, Clausiusstrasse 25, 8092 Zurich, Switzerland

2 U.S. Geological Survey, Volcano Science Center, Menlo Park, CA 94025, USA

3 Institut des Dynamiques de la Surface Terrestre, Université de Lausanne, 1015 Lausanne, Switzerland

\section{Introduction}

Primitive basalts at convergent margins provide valuable insights into magma generation beneath volcanic arcs. The North American Cascades are well-known for their variety of primitive magmas. Earlier studies of mafic magmas in the Cascades have established three compositional endmembers: (1) high-field strength element (HFSE-rich) basalts, also referred to as ocean-island basalts (OIB) or intraplate basalts (IPB); (2) low-K, high-Al olivine tholeiites (LKOT, HAOT); and (3) calc-alkaline arc basalts (CAB) and basaltic andesites (BA) (Bacon 1990; Leeman et al. 1990, 2005; Bacon et al. 1997; Borg et al. 1997; Clynne and Borg 1997; Conrey et al. 1997; Reiners et al. 2000; Grove et al. 2002; Smith and Leeman 2005; Hildreth 2007; Schmidt et al. 2008; 
Rowe et al. 2009; Moore and DeBari 2012; Sisson et al. 2014; Mullen et al. 2017). Minor variants include ultrapotassic shoshonites and absarokites (Bacon 1990; Conrey et al. 1997; Schmidt et al. 2008) as well as high-Mg andesites (Baker et al. 1994; Bacon et al. 1997; Clynne and Borg 1997; Grove et al. 2002; Sas et al. 2017; Streck and Leeman 2018). To avoid any interpretative association with a certain tectonic setting, we use the term HFSE-rich basalts (Schmidt et al. 2008) for basalts that lack or have small depletions of HFSE, high $\mathrm{Nb}$ concentrations, high light to heavy rareearth-element ratios (LREE/HREE) similar to OIB, and overall enriched concentrations in incompatible trace elements relative to mid ocean ridge basalts (MORB). LKOTs have variable compositions throughout the arc, but are comparable to enriched (E)-MORB, although with higher $\mathrm{Al}_{2} \mathrm{O}_{3}$ contents $(>17 \%)$ and slightly enriched incompatible traceelement abundances, albeit distinctly lower than in HFSErich basalts. $\mathrm{CAB}$ and $\mathrm{BA}$ compositions vary along-arc, but are commonly enriched in fluid-mobile large ion lithophile elements (LILE) and LREE relative to immobile HFSE and HREE, associated with a hydrous slab-derived component. The diversity among primitive basalts has been assigned to the existence of at least three mantle components that are irregularly distributed beneath the arc: (1) a source enriched in incompatible elements relative to MORB (similar to that producing OIB); (2) depleted sub-arc mantle similar to that producing MORB, but weakly modified by a subduction component (HAOT-/LKOT-type mantle); and (3) a modern slab-derived subduction component and/or mantle source metasomatized by ancient subduction-related fluids.

Mafic magmas are most abundant from southern Washington to Northern California, but all basalt types occur widely distributed along and across the arc (Hildreth 2007). Primitive magmas in the Cascades typically erupt from monogenetic and shield vents, but also erupt near stratovolcanoes that are dominated by andesite and/or dacite. When associated with stratovolcanoes, basalts preferentially erupt from the periphery of these systems and/or become more primitive with distance from the central vents. Examples include Mt. Baker (Moore and DeBari 2012), Mt. Rainier (Fiske et al. 1963; Sisson et al. 2014), Mt. Adams (Hildreth and Fierstein 1997), and Mt. Hood (Scott et al. 1997). Mount St. Helens (MSH) forms an exception with respect to basaltic vent localities. Different basalt types erupted through the axial system of the volcano, from vents on the southern and northern to northwestern flanks, less than 1-2 km from the main crater.

Descriptions of quaternary basaltic magmas in the MSH area can be found in Smith (1984), Leeman et al. (1990), Smith and Leeman (1993), Smith and Leeman (2005) and Leeman and Smith (2018). They defined three types of mafic magmas at MSH including (1) calc-alkaline olivine + plagioclase \pm clinopyroxene basalt enriched in $\mathrm{K}_{2} \mathrm{O}, \mathrm{TiO}_{2}$, and incompatible trace elements, also referred to as north flank basalt that is equivalent to our HFSE-rich basalt, (2) transitional olivine + plagioclase basalt with low $\mathrm{K}_{2} \mathrm{O}$ and incompatible trace-element abundances transitional between calcalkaline and tholeiitic basalts, the so-called Cave Basalt on the south flank of the volcano that we refer to as LKOT, and (3) olivine + plagioclase basaltic andesite with incompatible trace-element compositions intermediate between the two basalt types that represent mixtures of basaltic endmembers and variable amounts of more evolved calc-alkaline material (Leeman et al. 2005; Smith and Leeman 2005; Leeman and Smith 2018). These studies attributed the compositional diversity in mafic magmas to different degrees of relatively dry melting of a heterogeneous mantle.

Although the previous studies address the petrogenesis of some mafic magmas at $\mathrm{MSH}$, new geologic mapping, geochronologic data (Clynne et al. 2008), and accompanying chemical data revealed a refined stratigraphy with at least eight basaltic and basaltic andesitic units (summarized in Pallister et al. 2017). Combined with recent geophysical imaging (Hansen et al. 2016; Kiser et al. 2016, 2018), these new data provide the background for a more detailed investigation of mafic magmas at MSH.

This study presents new major and trace-element compositions for 45 samples erupted during the Castle Creek period, including $\mathrm{Sr}-, \mathrm{Nd}-$, and $\mathrm{O}$ isotopes for 12 samples and mineralogic data for 6 mafic units. Furthermore, a data compilation of Castle Creek rocks with whole-rock compositions from the literature and 287 previously unpublished samples, mostly obtained during mapping of the volcano by E. Wolfe and M. Clynne, is presented. These reveal remarkable geochemical trends and compositional endmembers, partly differing from those defined by Smith and Leeman (1993) and Leeman and Smith (2018). Using the extended data set and petrologic data, the aims are to (1) specify the characterization of different mafic endmembers at MSH, (2) evaluate pre-existing hypotheses concerning their origin, and (3) focus on the implications of the observed chemical and petrological variability for the MSH magmatic system, particularly considering the close spatial and temporal eruption of different basalt types, andesites, and dacites.

\section{Geologic setting}

MSH is a dominantly dacitic stratovolcano that lies about $50 \mathrm{~km}$ west of the main volcanic axis in the southern Washington Cascades. The area belongs to the Columbia segment of the arc (Schmidt et al. 2008), where the Juan de Fuca plate is subducted beneath North America. The oblique subduction induces dextral shear between the two plates and results in clockwise rotation of large crustal blocks, such as the Oregon forearc block, that leads to 
northward translation of the forearc and intra-arc extension (Wells et al. 1998; Hildreth 2007). MSH is located in a small tensional pull-apart basin formed by a dextral offset in the N-NW-trending right-lateral strike-slip fault system known as the St. Helens seismic zone (SHSZ) that intersects with an NE-trending set of pre-Quaternary fractures (Fig. 1) (Weaver et al. 1987). The SHSZ coincides with the eastern boundary of the oceanic Siletzia terrane (Parsons et al. 1999) that was accreted to North America in the early Eocene (Wells et al. 2014) and with the western boundary of the Spirit Lake batholith (Bedrosian et al. 2018). Recent geophysical imaging revealed two low velocity zones interpreted as magma storage zones in the upper and lower crust beneath MSH (Kiser et al. 2016). The lower crustal velocity anomaly appears to be shifted about $10-20 \mathrm{~km}$ southeast of the volcano and extends from about $20 \mathrm{~km}$ depth to the Moho at $40 \mathrm{~km}$.

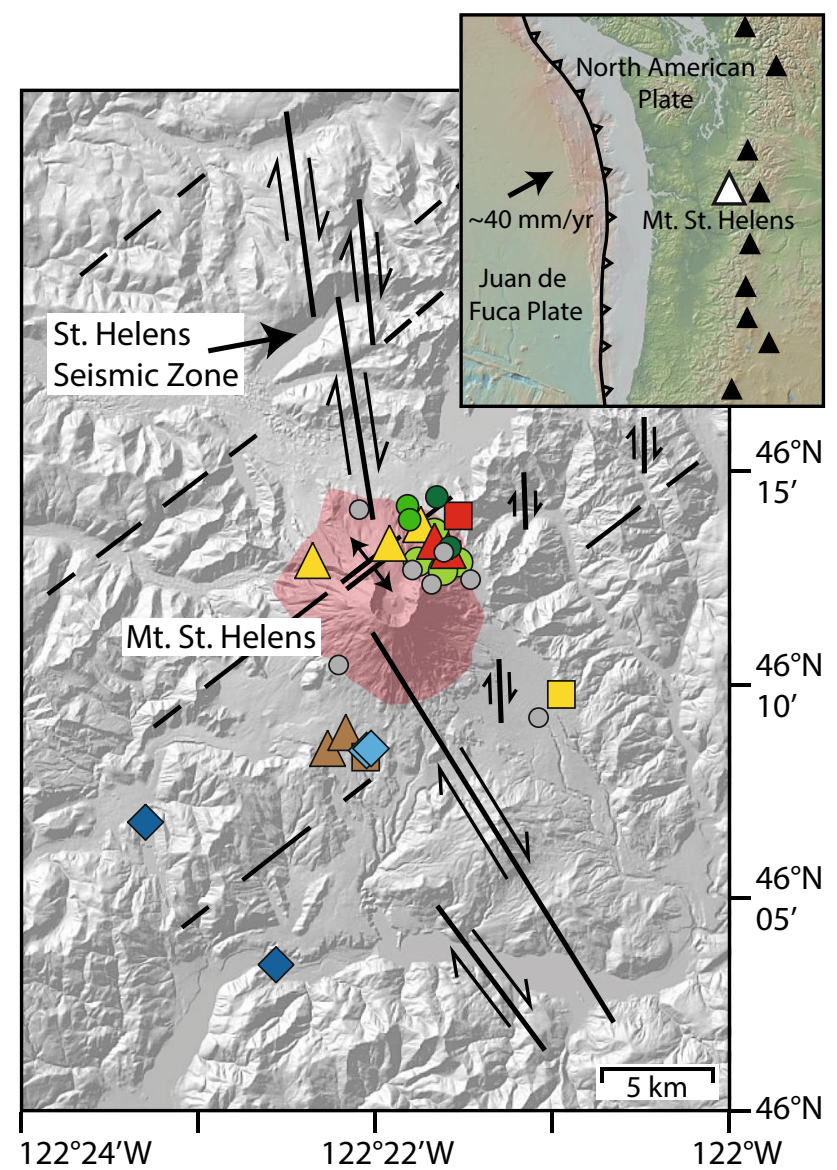

Fig. 1 Shaded relief map of the Mount St. Helens area showing sample localities of Castle Creek rocks. Symbols and colors for different units are explained in Table 1. Black lines show major tectonic boundaries as discussed by Weaver et al. (1987) including the NNWstriking St. Helens seismic zone and a pre-Quaternary NE-striking set of fractures. The inset map indicates the position of Mount St. Helens about $50 \mathrm{~km}$ west of the main volcanic axis of the Cascade arc

\section{Eruptive history}

The modern edifice of MSH developed over the last $4 \mathrm{ka}$, but volcanism in the MSH area dates back to at least $270 \mathrm{ka}$ (Clynne et al. 2008), and Claiborne et al. (2010) reported sparse zircons as old as 500-600 ka in some of the dacites. The stratigraphy of pyroclastic deposits of the volcano has been well-established by Crandell and Mullineaux in the 1960s-1980s (Crandell 1987; Mullineaux 1996). It was recently refined by new geological mapping aided by argon and radiocarbon geochronology, and paleomagnetic directional data (Clynne et al. 2008 and Appendix A1). The eruptive history of MSH has been divided into four eruptive stages separated by repose intervals of several 1000 years. The youngest stage, Spirit Lake, has been further subdivided into seven eruptive periods separated by dormant intervals of several 100 years: Smith Creek (3.9-3.3 ka), Pine Creek (3.0-2.55 ka), Castle Creek (2.025-1.7 ka), Sugar Bowl (1.05 ka), Kalama (1479-1725 CE), Goat Rocks (1800-1857 CE), and Modern (1980-present) eruptive periods.

The Castle Creek eruptive period was the most compositionally diverse period in the volcano's history and the only one that erupted basalts. Compositions from dacite to basalt were erupted between $\sim 2025$ and 1700 years B.P. in three phases (Table 1) (Pallister et al. 2017). The early phase ( 2025-1990 years B.P.) primarily encompassed dacitic eruptions of lava domes, pyroclastic flows and lahars, tephra Bi, and several silicic andesitic-to-dacitic lava flows. Deposits of the middle Castle Creek phase are confined to the southern flank of the volcano. They include three compositionally different basalt units (erupted around 1895 years B.P.). During the late Castle Creek phase ( 1800-1700 years B.P.,) a number of basaltic-to-dacitic lavas and tephras were emplaced on the northern and eastern flanks of the volcano. The most prominent departures from the stratigraphy established by Crandell and Mullineaux are the redefinition of some basaltic andesitic and andesitic tephras (Bh, Bo) and lavas previously recognized as Castle Creek age to Pine Creek age and the recognition that the basaltic tephra $\mathrm{Bu}$ consists of three eruptions (Bu1, Bu2, Bu3) of different ages. This redefined the Castle Creek basalts on the southern flank to be older than those on the northern flank.

\section{Analytical methods}

\section{Major and trace elements}

The abundances of major element oxides from 45 samples of the Castle Creek eruptive period were analyzed by 
Table 1 Stratigraphy of the Castle Creek eruptive period of Mount St. Helens

\begin{tabular}{|c|c|c|c|c|}
\hline Age & Symbol & Unit* & Abbr. & Rock type \\
\hline \multicolumn{5}{|c|}{ Late Castle Creek period ( 1895-1700 years BP) } \\
\hline & 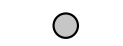 & Andesite of Loowit Trail & alt & lava flow, breccia \\
\hline & & Basaltic andesite of Nelson Glacier & mng & lava flows \\
\hline \multirow[t]{3}{*}{$\begin{array}{l}1730 \pm 35 \mathrm{BP} \\
1740 \pm 70 \mathrm{BP}\end{array}$} & $\triangle /$ & Basalt of Castle Creek/Bu3 tephra & $\mathrm{bcc} / \mathrm{Bu} 3$ & lava flows/tephra \\
\hline & O & Andesite of the Baguette flow (?) & $\mathrm{ab}$ & lava flow \\
\hline & O & Andesite of the Plains of Abraham & apa & lava flows \\
\hline \multirow[t]{4}{*}{$\begin{array}{l}1765 \pm 40 \mathrm{BP} \\
1795 \pm 30 \mathrm{BP}\end{array}$} & & Andesite of Sasquatch Steps & asa & $\begin{array}{l}\text { lava flows, lahar, } \\
\text { pyroclastic flows }\end{array}$ \\
\hline & & Basalt of the north flank, Bu2 tephra & bnf/Bu2 & lava flows/tephra \\
\hline & & Basaltic andesite of Truman Trail & $\mathrm{mtt}$ & lava flows \\
\hline & $\Omega$ & Andesite of section 26 & a26 & lava flows \\
\hline \multicolumn{5}{|c|}{ Middle Castle Creek period $(\sim 1895 \pm 10$ years BP) } \\
\hline \multirow[t]{3}{*}{$1895 \pm 10 \mathrm{BP}$} & & Cave Basalt & $\mathrm{bc}$ & lava flows \\
\hline & & Pre-Cave Basalt (high-K/low-K) & bpc & lava flows \\
\hline & & Basalt of the south flank/Bu1 tephra & $\mathrm{bsf} / \mathrm{Bu} 1$ & lava flows/tephra \\
\hline \multicolumn{5}{|c|}{ Early Castle Creek period ( 2025-1990 years BP) } \\
\hline & $\bigcirc$ & $\begin{array}{l}\text { Dacite of Redrock Pass (?), Andesite of } \\
\text { the North Rim, Dogs Head dome }\end{array}$ & dcc & $\begin{array}{l}\text { lava flows, lava } \\
\text { domes }\end{array}$ \\
\hline & 0 & Bi tephra & $\mathrm{Bi}$ & tephra \\
\hline $\begin{array}{l}1990 \pm 40 \mathrm{BP} \\
2025 \pm 40 \mathrm{BP}\end{array}$ & 0 & $\begin{array}{l}\text { Northwest dome, Dacitic lahars and } \\
\text { pyroclastic flows }\end{array}$ & $\mathrm{dcc}$ & $\begin{array}{l}\text { lava dome, lahars, } \\
\text { pyroclastic flows }\end{array}$ \\
\hline
\end{tabular}

*Units (bcc, bpc, bsf) that encompass basaltic and basaltic andesitic compositions are referred to as basalts

X-ray fluorescence analysis (XRF) using a PANalytical AXIOS spectrometer at ETH Zürich. Trace elements were measured by laser ablation-inductively coupled plasma source mass spectrometry (LA-ICPMS) on the fused glass beads used for XRF analyses using a Geolas Laser Ablation System coupled with an Elan 6100 DRC (Perkin Elmer) mass spectrometer. Samples, blanks, and standards were ablated for $60 \mathrm{~s}$ with $10 \mathrm{~Hz}$ and a beam diameter of $90 \mu \mathrm{m}$ (except for an NIST 610 standard that was ablated with a beam diameter of $40 \mu \mathrm{m}$ ). The data were processed using the data reduction software SILLS (Guillong et al. 2008). All data and results for a BCR-2 standard and duplicates analyzed along with the sample suite for major and trace elements are reported in Appendix A2.

\section{Isotopes}

Strontium and neodymium isotope compositions of 12 samples were analyzed on 50-70 mg whole-rock powder digested in $\mathrm{HF}$ and $\mathrm{HNO}_{3}$. $\mathrm{Sr}$ and $\mathrm{Nd}$ were subsequently separated by ion-exchange chromatography in columns with SrSpec, TRUSpec, and LnSpec Eichrom resins (Pin et al. 1994). Strontium was loaded onto outgassed Re single filaments with $\mathrm{HNO}_{3}$ and Ta emitter, whereas the
$\mathrm{Nd}$ fraction was loaded onto double filaments with $2 \mathrm{~N}$ $\mathrm{HCl}$. Both were analyzed with a Thermo Scientific TritonPlus mass spectrometer operated in static mode at ETH Zürich. Repeated measurements of NBS 987 and JNd-i yielded an ${ }^{87} \mathrm{Sr} /{ }^{86} \mathrm{Sr}$ mean ratio of $0.710234 \pm 0.000004$ and an ${ }^{143} \mathrm{Nd} /{ }^{144} \mathrm{Nd}$ mean ratio of $0.512100 \pm 0.000003$, respectively.

Oxygen was extracted by $\mathrm{CO}_{2}$ laser fluorination using about 50 mbars of $\mathrm{F}_{2}$ as reagent at the University of Lausanne. The $\mathrm{CO}_{2}$ laser was pulsed at a rate of $50 \mathrm{~Hz}$ with a duration of $20 \mathrm{~ms}$, and the beam size was successively lowered from 1850 to $260 \mu \mathrm{m}$. Oxygen was cleaned from residual $\mathrm{F}_{2}$ by passing the gas over heated $\mathrm{KCl}$ and adsorbing the oxygen on a molecular sieve $(13 \times)$ prior to expanding it into the dual inlet of a Thermo Finnigan MAT 253 mass spectrometer. Oxygen isotope compositions are reported relative to standard mean ocean water (VSMOW) in the common $\delta$-notation in parts per thousand (\%o, permil). NBS-28 quartz standard $(9.64 \%$ ) was used for reference and drift correction for each run. The analyses were performed on $1.7-2.7 \mathrm{mg}$ of whole-rock powder and $0.5-2.4 \mathrm{mg}$ mineral separates, respectively. Duplicate analyses for different days reproduced to an average precision of better than $\pm 0.2 \%$. $\mathrm{Sr}, \mathrm{Nd}$, and $\mathrm{O}$ isotopic ratios are given in Appendix A2. 


\section{Mineral analyses}

Backscattered electron images of thin sections and mineral grain mounts were obtained using a JEOL JSM-6390LA scanning electron microscope (SEM) at the ETH Zürich. Analyses of major and some minor elements in minerals were performed on a JEOL JXA-8200 electron probe micro analyzer (EPMA) at the ETH Zürich using five wavelength dispersive spectrometers. Plagioclase was measured using $15 \mathrm{kV}$ accelerating voltage, $10 \mathrm{nA}$ beam current, and a spot size of $5 \mu \mathrm{m}$. Na and $\mathrm{K}$ were analyzed first. Olivine was analyzed with $20 \mathrm{kV}, 30 \mathrm{nA}$, and a focused beam, spinel with $15 \mathrm{kV}, 30 \mathrm{nA}$, and a focused beam. V and Mn were corrected for $\mathrm{K}_{\beta}$ peak overlaps of $\mathrm{Ti}$ and $\mathrm{Cr}$. All mineral data and details about calibration, standard analyses, and errors are reported in Appendix A3.

\section{Geochemical characteristics}

\section{Major and trace elements}

Volcanic rocks erupted during the Castle Creek period from MSH encompass basaltic through dacitic compositions, with a great heterogeneity at the mafic end of the spectrum. Mafic rocks include basalts, trachybasalts, and basaltic andesites (Fig. 2a) (Le Bas et al. 1986). They have medium-K, subalkaline compositions, with exception of the highest $\mathrm{K}$ basalts that are alkaline (Fig. 2b) (Irvine and Baragar 1971; Gill 1981). High $\mathrm{FeO} / \mathrm{MgO}$ ratios classify the basalts as tholeiitic, whereas basaltic andesites to dacites are predominantly calc-alkaline (Fig. 2c) (Miyashiro 1974).

Three groups of mafic magma are identified at MSH that each resemble more primitive variants of the same type in the Cascades: (1) HFSE-rich basalts encompassing alkaline and calc-alkaline high-K basalts (bsf/Bu1, bnf/Bu2, bcc/ Bu3; unit names as in Table 1); (2) LKOT formed by low-K basalts (bc, bpc); and (3) calc-alkaline or arc-type basaltic andesites (mng, ass, $\mathrm{mtt}$ ), which are relatively evolved, but represent the most mafic variants of this rock type at MSH (Figs. 2, 3). The first two endmembers are equivalent to basalts described by Smith and Leeman (1993) and Leeman and Smith (2018). We will refer to the third endmember as arc-type basaltic andesites to distinguish them from previously described calc-alkalic basaltic andesites (as defined by Miyashiro 1974) that have lower $\mathrm{SiO}_{2}$ contents, but lack pronounced chemical arc signatures (i.e., enrichment in LILE and LREE relative to HFSE and HREE). The most notable features of Castle Creek rocks are the two distinct chemical trends from the HFSE-rich and LKOT-like basalt endmembers that almost merge around 5-6 wt $\% \mathrm{MgO}$ and 52-54 wt $\% \mathrm{SiO}_{2}$ (Figs. 2, 3, 4).
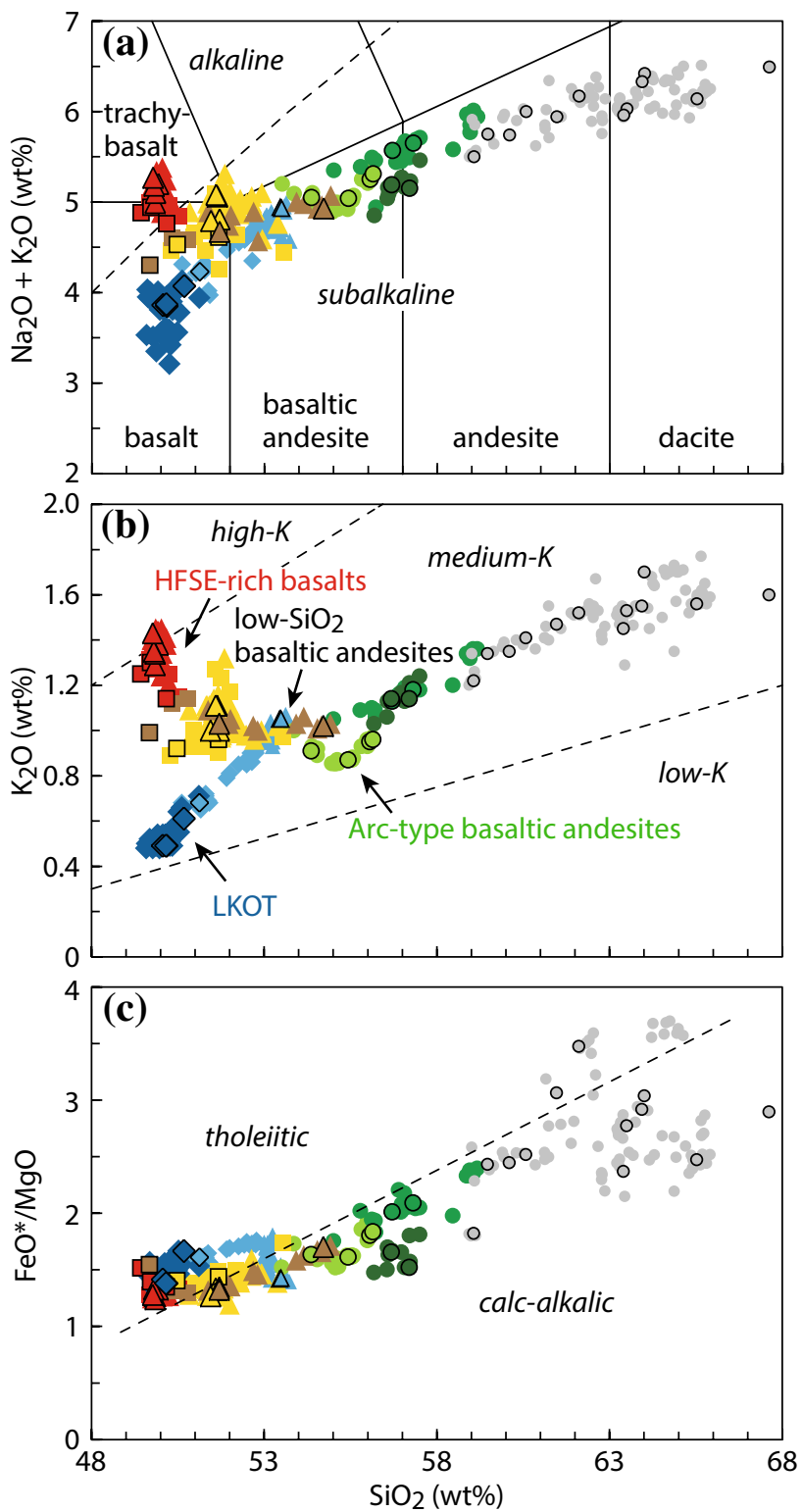

Fig. 2 Major element variations vs. $\mathrm{SiO}_{2}$ of volcanic rocks from the Castle Creek period of Mount St. Helens. Each color refers to a single mafic unit (same as in Table 1). Symbols outlined in black indicate samples from this study; others compile literature and previously unpublished data (Appendix A4). All whole-rock data are normalized to $100 \%$ with $\mathrm{FeO}^{*}$ recalculated as $\mathrm{FeO}$ and $\mathrm{Fe}_{2} \mathrm{O}_{3}$ assuming $\mathrm{Fe}^{3+} /$ $\Sigma \mathrm{Fe}=0.2$, except for the LKOT endmember (Cave Basalt, $\mathrm{Fe}^{3+}$ / $\Sigma \mathrm{Fe}=0.15$ ). a Total alkali vs. silica (TAS) diagram after Le Bas et al. (1986) showing the classification of Castle Creek rocks. The dashed line divides alkaline and subalkaline rocks (Irvine and Baragar 1971). b $\mathrm{K}_{2} \mathrm{O}$ vs. $\mathrm{SiO}_{2}$. Dashed lines separate the fields of low-K, medium$\mathrm{K}$, and high-K after Gill (1981). c FeO*/MgO. Fields for tholeiitic and calc-alkalic rocks are shown after Miyashiro (1974)

\section{HFSE-rich basalts}

The basalt of the north flank (bnf) and the associated tephra layer Bu2 form the endmember of the HFSE-rich basalts. 

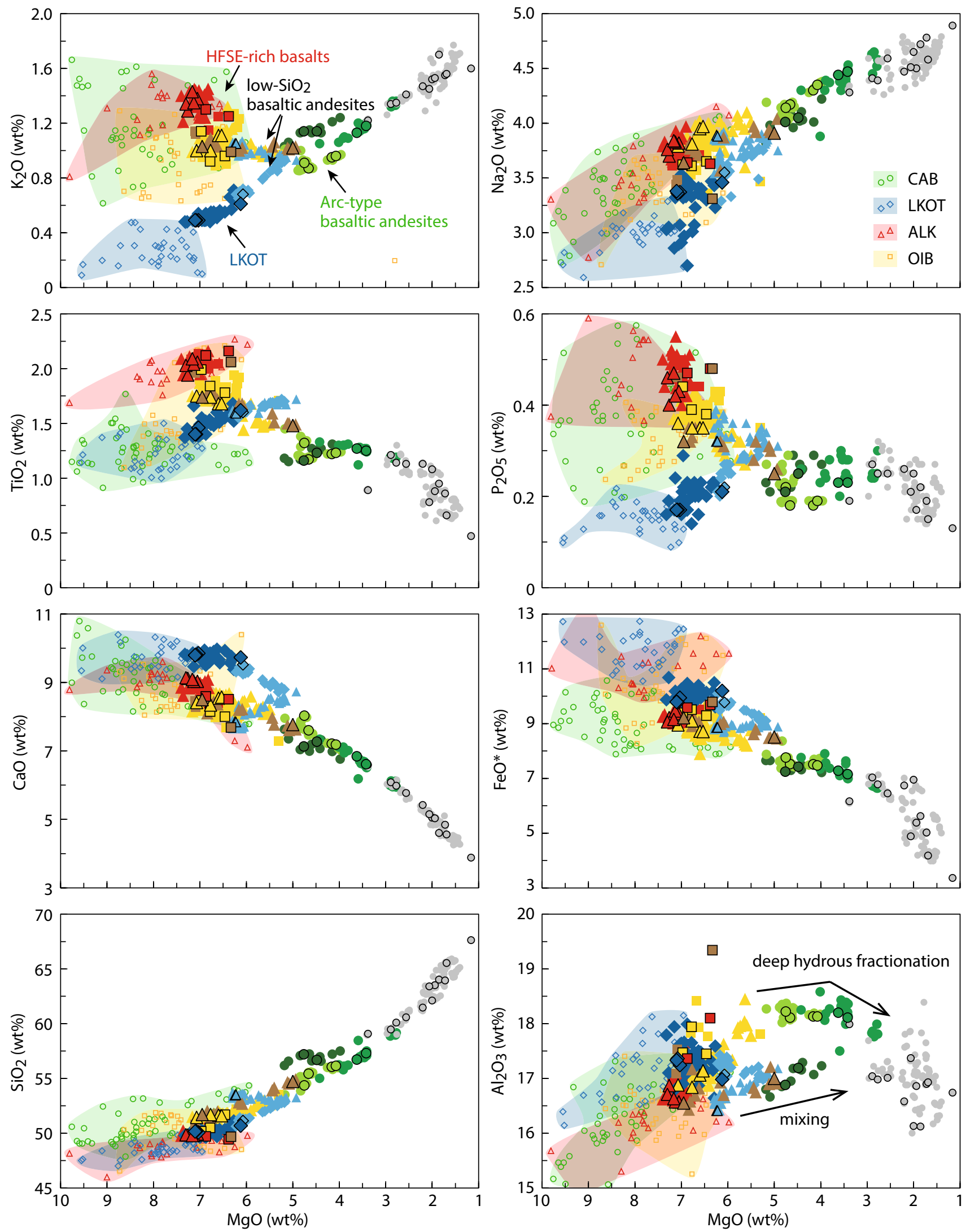
4Fig. 3 Major element variations vs. MgO. Symbols as in Table 1. Shaded fields show compositions of different types of primitive basalts across the southern Washington Cascades taken from Leeman et al. (2005) and references therein: calc-alkaline basalts (CAB), low-K olivine tholeiites (LKOT), nepheline-normative ocean-islandtype (ALK) basalts, and hypersthene-normative ocean-island-type basalts (OIB)

They are characterized by high abundances of $\mathrm{K}_{2} \mathrm{O}, \mathrm{Na}_{2} \mathrm{O}$, $\mathrm{TiO}_{2}$, and $\mathrm{P}_{2} \mathrm{O}_{5}$ (Fig. 3). Their compositions overlap with those of nepheline-normative HFSE-rich basalts in the southern Washington Cascades ( $A L K$, Leeman et al. 2005) (Figs. 3, 4). They have high incompatible trace-element abundances closely approaching those of OIB (Fig. 5). Their high LREE/HREE ratios $(\mathrm{La} / \mathrm{Yb}=8.6-12.9)$ produce patterns roughly parallel to those of the Castle Creek dacites, but at higher total abundances. None of the basalts at $\mathrm{MSH}$ has a pronounced Eu anomaly $\left(\mathrm{Eu} / \mathrm{Eu}^{*}=0.92-1.08\right)$. HFSE-rich basalts are slightly enriched in LILE and HFSE over REE relative to MORB $(\mathrm{Ba} / \mathrm{La}=13.7-14.8, \mathrm{~Pb} /$ $\mathrm{Ce}=0.04-0.06)$ and have positive $\mathrm{Nb}-\mathrm{Ta}$ anomalies $(\mathrm{Nb} /$ $\mathrm{La}=1.3-1.5)$.

The basalt of Castle Creek (bcc) with the associated tephra layer Bu3 and the basalt of the south flank (bsf) form nearly continuous chemical trends towards $\left(\right.$ low- $\left.-\mathrm{SiO}_{2}\right)$ basaltic andesite. These more evolved units have lower abundances of incompatible trace elements and show depletion in $\mathrm{Nb}$ and Ta with decreasing $\mathrm{MgO}(\mathrm{Nb} / \mathrm{La}=1.5-0.8)$. Some of these samples resemble more primitive hypersthene-normative HFSE-rich basalts in the southern Washington Cascades (OIB, Leeman et al. 2005).

\section{LKOT}

The LKOT endmember is represented by the $0.25 \mathrm{~km}^{3}$ (Williams et al. 2004) Cave Basalt (bc) lava flow on the southern flank of MSH. It has compositions closely approaching those of primitive southern Washington LKOTs (Leeman et al. 2005), but with slightly higher abundances of incompatible elements due to its more evolved nature $(\mathrm{MgO}=6.1-7.3 \mathrm{wt} \%)$. The Cave Basalt has distinctly lower abundances of $\mathrm{K}_{2} \mathrm{O}, \mathrm{Na}_{2} \mathrm{O}, \mathrm{TiO}_{2}$, and $\mathrm{P}_{2} \mathrm{O}_{5}$, and higher abundances of $\mathrm{CaO}, \mathrm{FeO}$, and $\mathrm{Al}_{2} \mathrm{O}_{3}$ than HFSE-rich basalts. It also has lower concentrations of most incompatible trace elements. Some elements (e.g., Ni, Cr, V, and Y) occur in the same abundance as in HFSE-rich basalts. Incompatible trace elements exceed those of enriched (E)-MORB. They are slightly enriched in LREE over HREE $(\mathrm{La} / \mathrm{Yb}=3.4-4.1)$ and LILE relative to REE $(\mathrm{Ba} / \mathrm{La}=13-15, \mathrm{~Pb} / \mathrm{Ce}=0.08-0.10)$ (Fig. 5). Some Cave Basalt samples have a weak negative $\mathrm{Nb}$-Ta-anomaly $(\mathrm{Nb} / \mathrm{La}=0.8-1.0)$.

The pre-Cave basalt (bpc) that preceded the eruption of the Cave Basalt forms a compositional trend from this LKOT endmember towards basaltic andesite (Fig. 2). On compositional variation diagrams against $\mathrm{MgO}$, the preCave Basalt forms a high- $\mathrm{K}$ to low- $\mathrm{K}$ trend that merges at basaltic andesitic compositions, but at higher $\mathrm{TiO}_{2}$ and $\mathrm{CaO}$ contents than basaltic andesites of the HFSE-rich basalt group (Fig. 3). Incompatible trace elements exceed those of the Cave Basalt.

\section{Arc-type basaltic andesites}

Previously undescribed arc-type basaltic andesites include the basaltic andesite of Nelson Glacier (mng), the basaltic andesite of Truman Trail (mtt), and the andesite of Sasquatch Steps (asa). Despite some variability among these units, the basaltic andesite of Nelson Glacier is used to represent this group, as it shows the least disequilibrium textures (Appendix A5). Primitive CAB did not erupt from MSH; thus, the basaltic andesite of Nelson Glacier represents the most mafic endmember of this magma type. Its compositions plot close to the converging point of the LKOT and HFSE-rich basalt groups, but at higher $\mathrm{Al}_{2} \mathrm{O}_{3}$ and lower $\mathrm{TiO}_{2}, \mathrm{FeO}$, and $\mathrm{P}_{2} \mathrm{O}_{5}$, similar to Cascade CAB (Fig. 3). Arc-type basaltic andesites have steep REE patterns $(\mathrm{La} / \mathrm{Yb}=6.4-9.2)$ and show distinct enrichment in fluid-mobile LILE, $\mathrm{U}$ and $\mathrm{Pb}$ $(\mathrm{Ba} / \mathrm{La}=19.2-23.0, \mathrm{~Pb} / \mathrm{Ce}=0.12-0.17)$ and depletion in immobile HFSE $(\mathrm{Nb} / \mathrm{La}=0.5-0.7)$ typical for subductionrelated magmas. Their incompatible trace-element patterns are similar to those of MSH andesites and dacites, but different from the two basalt groups.

\section{Isotopic compositions}

Sr- and Nd-isotope compositions were determined for representative samples of the Castle Creek period covering basaltic-to-dacitic compositions. $\mathrm{Nd}$ isotope compositions decrease from $\varepsilon_{\mathrm{Nd}}=7.7$ in the basalts to $\varepsilon_{\mathrm{Nd}}=4.4$ in the dacites, whereas $\mathrm{Sr}$ isotope compositions increase from about ${ }^{87} \mathrm{Sr} /{ }^{86} \mathrm{Sr}=0.7030$ to 0.7038 (Fig. 6a). Both are in the range of isotopic compositions of primitive Cascade basalts (Mullen and McCallum 2014) and are consistent with literature data for MSH basalts and dacites (Halliday et al. 1983; Leeman et al. 1990). There is no distinct difference in $\mathrm{Sr}$ and $\mathrm{Nd}$ isotope compositions between HFSE-rich basalt and LKOT. ${ }^{87} \mathrm{Sr} /{ }^{86} \mathrm{Sr}$ ratios slightly increase with increasing whole-rock $\mathrm{SiO}_{2}$ (Fig. 6b).

Whole-rock $\delta^{18} \mathrm{O}$ values average at $5.7 \%$ in the basalts and $6.8 \%$ in the dacites (Fig. 6c). They are comparable to values measured in earlier studies (Halliday et al. 1983; Leeman et al. 1990). The two basaltic endmembers have similar $\delta^{18} \mathrm{O}$ values in the range of MORB (5.5-5.9\%o, Bindeman 2008). $\delta^{18} \mathrm{O}$ values increase with ${ }^{87} \mathrm{Sr} /{ }^{86} \mathrm{Sr}$ and whole-rock $\mathrm{SiO}_{2}$ above the amount expected from closed-system differentiation (Fig. 6d) (0.3-0.4\%o for fractionation from basalt to rhyolite, Bindeman 2008). $\delta^{18} \mathrm{O}$ is always higher 

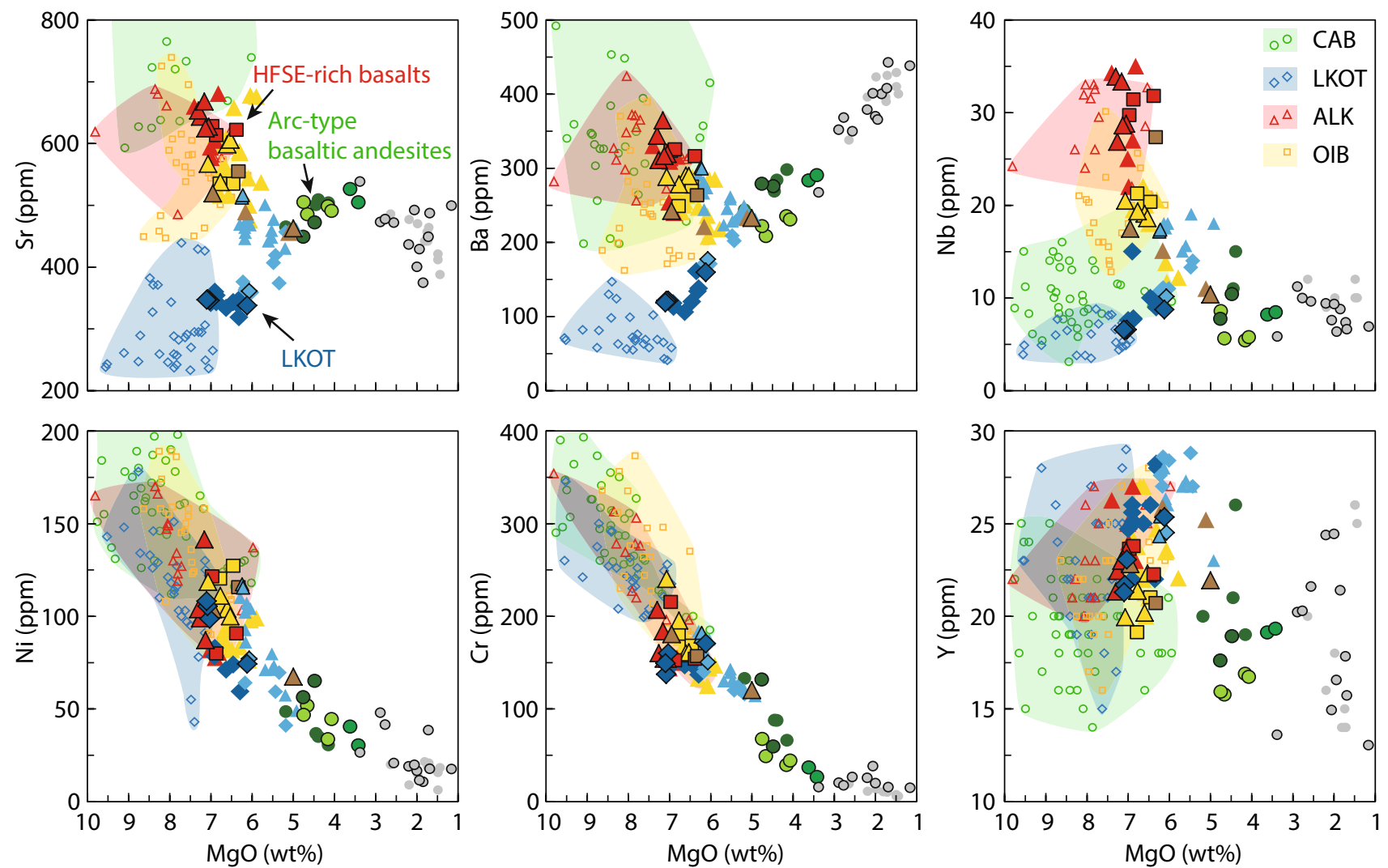

Fig. 4 Trace-element variations in Castle Creek rocks. Most incompatible trace elements form trends from LKOT and HFSE-rich basalt endmembers towards basaltic andesite as shown by most major ele-

ments. Symbols and fields as in Fig. 3. Some more compatible elements occur in the same abundances in both series

in plagioclase (5.8-6.8\%o) compared to whole-rock values, and is lower in olivine (5.1-5.7\%o). However, the difference between minerals and whole rocks is variable $\left(\Delta^{18} \mathrm{O}_{\mathrm{plg}-\mathrm{wr}}\right.$ $=0.1-1.1 \%$ and $\Delta^{18} \mathrm{O}_{\mathrm{wr}-\mathrm{ol}}=0.3-0.8 \%$ o $) . \Delta^{18} \mathrm{O}_{\mathrm{plg}-\mathrm{ol}}$ values are scattering from 0.4 to $1.4 \%$ compared to $0.6-0.8 \%$ o expected from experimentally determined fractionation at $1200-1300{ }^{\circ} \mathrm{C}$ (Chiba et al. 1989; Eiler 2001). This range is larger than that given for the average analytical precision of $\pm 0.2 \%$ o, suggesting that the phenocrysts analyzed are not in direct oxygen isotope equilibrium for at least some of the samples.

\section{Petrography and mineral chemistry}

Most basalts and basaltic andesites of MSH are porphyritic (10-30 vol\% crystals) with an assemblage dominated by olivine and plagioclase (except for the basalt of the south flank, which contains only a few percent of olivine in some flows). Chromian spinel occurs as small inclusions in some olivine crystals. Some basaltic-to-basaltic andesitic flows (bsf, bpc, bcc, mng) contain small, sparse clinopyroxene. The finegrained matrices are composed of plagioclase (plg), olivine (ol), clinopyroxene (cpx), titano-magnetite (mgt), ilmenite (ilm), rare apatite (apt), and interstitial glass or, in the case of the tephras, a glassy matrix. The Cave Basalt (LKOT endmember) differs texturally from HFSE-rich basalts by a high abundance of glomerocrystic aggregates (Fig. 7a) that are rare in other basalts. Petrographic descriptions of all Castle Creek units are given in Appendix A5.

\section{Plagioclase}

Plagioclase is the most abundant phase (5-30 vol\%) in most mafic rocks. Sizes typically range from microphenocrysts (tens of $\mu \mathrm{m}$ ) to phenocrysts of $1-4 \mathrm{~mm}$. Plagioclase phenocrysts in the Cave Basalt (LKOT) are normally zoned with anorthite (An) contents ranging from $\mathrm{An}_{75}$ to $\mathrm{An}_{60}$ (Fig. 8). Single crystals have the same compositions as those in glomerocrystic aggregates, suggesting entrainment of cognate crystal mush. In contrast, all the other mafic magmas contain complexly/reversely zoned crystals (abundant in basalts, but also common in arc-type basaltic andesites) in addition to usually smaller, normally zoned varieties. They have lowAn antecrystic cores (typically $\mathrm{An}_{70-40}$, but reaching $\mathrm{An}_{32}$ ) that form dark areas on SEM images (Fig. 7b-d). These 

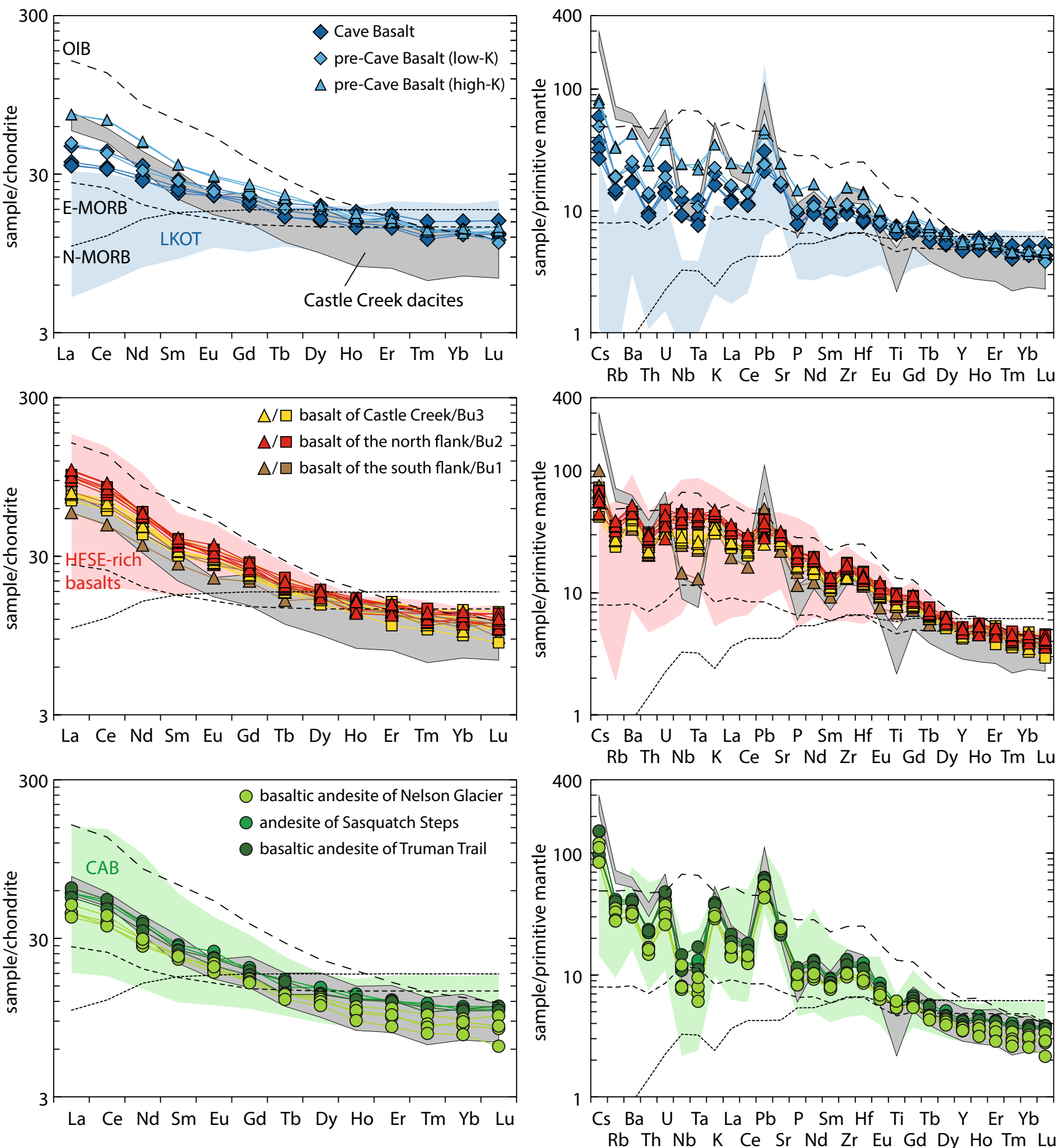

Fig. 5 Rare-earth elements (left) and incompatible trace elements (right) normalized to chondrite and primitive mantle (Sun and McDonough 1989), respectively, in LKOT, HFSE-rich basalts, and arc-type basaltic andesites. Compositions of Castle Creek dacites,

cores often have complex zonation patterns, sieve-textured horizons, or can be completely resorbed and replaced by a microcrystalline mixture of $\mathrm{plg}, \mathrm{cpx}$, mgt, ilm, and glass. Rims of these reversely zoned crystals show normal zoning

Cascade LKOT, HFSE-rich basalts and CAB (colored fields, Mullen et al. 2017), and normal mid ocean ridge basalts (N-MORB), enriched (E)-MORB, and ocean-island basalts (OIB) (Sun and McDonough 1989) are shown for comparison

with compositions similar to normally zoned phenocrysts $\left(\mathrm{An}_{78-64}\right.$ in HFSE-rich basalts, $\mathrm{An}_{74-44}$ in the arc-type basaltic andesite; Fig. 8). For comparison, zoned plagioclase in the dacitic $\mathrm{Bi}$ tephra is restricted to compositions of $\mathrm{An}_{39-60}$, 
Fig. 6 Isotopic compositions of Castle Creek period rocks spanning basaltic-to-dacitic compositions. Isotope data from Halliday et al. (1983) and Leeman et al. (1990) are shown for comparison. a ${ }^{143} \mathrm{Nd} /{ }^{144} \mathrm{Nd}$ vs. ${ }^{87} \mathrm{Sr} /{ }^{86} \mathrm{Sr}$. The gray field indicates compositions of primitive Cascade arc rocks (Mullen and McCallum 2014 and references therein). The inset shows the samples in a broader isotopic framework including bulk silicate earth (BSE), depleted mantle (DM), high ' $\mu$ ' $={ }^{238} \mathrm{U} /{ }^{204} \mathrm{~Pb}$ (HIMU), and enriched mantle 1 and 2 (EMI and EMII). b ${ }^{87} \mathrm{Sr} /{ }^{86} \mathrm{Sr}$ vs. $\mathrm{SiO}_{2}, \mathbf{c} \delta^{18} \mathrm{O}$ vs. ${ }^{87} \mathrm{Sr} /{ }^{86} \mathrm{Sr}$, and $\mathbf{d} \delta^{18} \mathrm{O}$ vs. $\mathrm{SiO}_{2}$ of whole rocks and plagioclase and olivine separates. Fields for mid ocean ridge basalts (MORB) and the array of $\delta^{18} \mathrm{O}$ during closed-system differentiation are taken from Bindeman (2008)
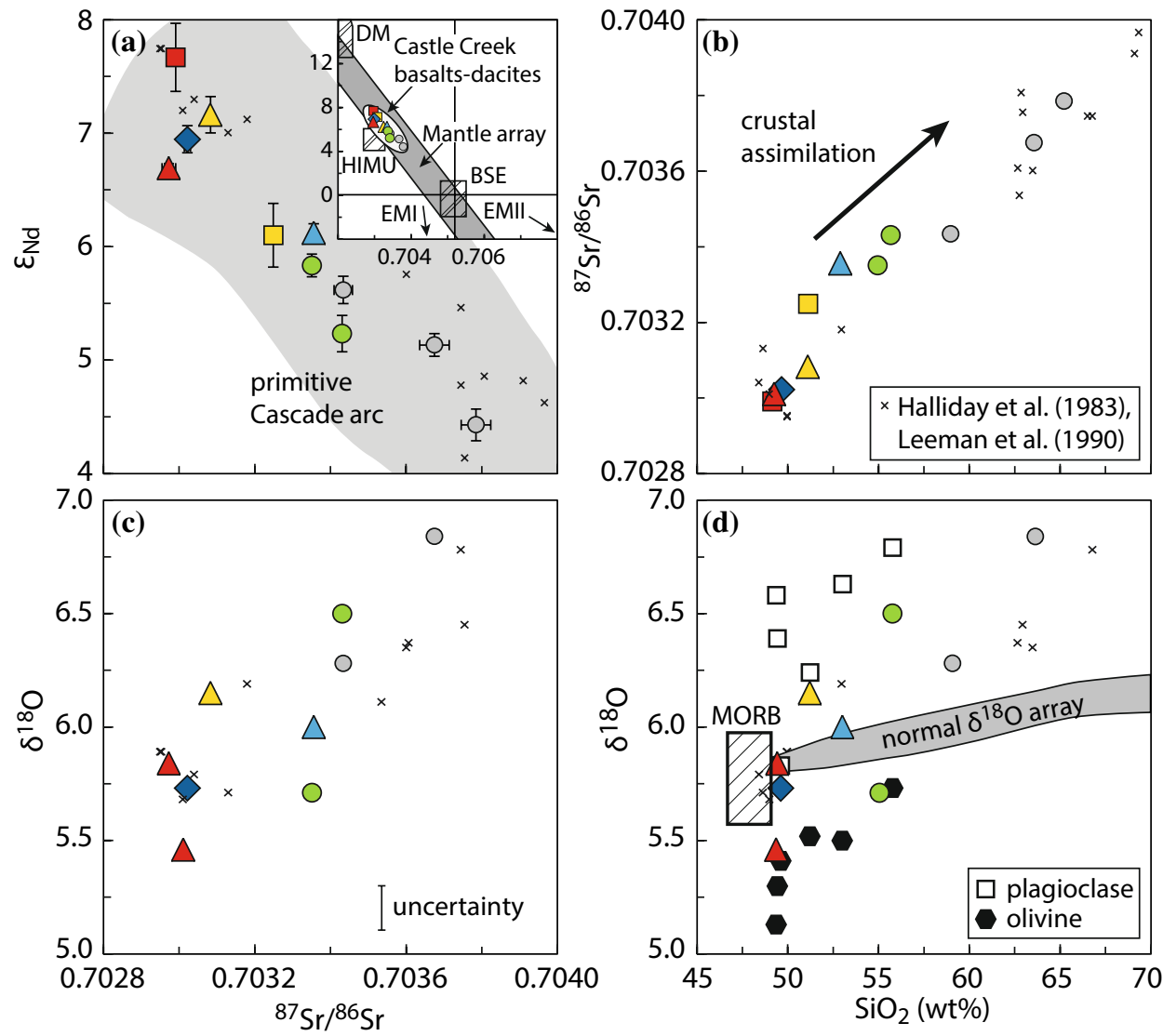

whereas the dacite of Red Rock Pass contains reversely zoned crystals with compositions of $\mathrm{An}_{41-65}$ and normally zoned crystals with $\mathrm{An}_{80-64}$.

\section{Olivine}

Olivine is ubiquitous in all basalts and basaltic andesites (1-8 vol\%). In general, the crystals are normally zoned with a forsterite $(\mathrm{Fo})$-rich core and a thin $(<10 \mu \mathrm{m})$ more fayalite $(\mathrm{Fa})$-rich rim when in contact with the groundmass (Fig. 7a, e). This rim is lacking when olivines are touching other grains, indicating rapid growth during final ascent, extrusion, and solidification of the basalts. Olivine crystals in arc-type basaltic andesite are less abundant than in basalts and rimmed by orthopyroxene (Fig. 7f). Olivine compositions range from $\mathrm{Fo}_{86}$ to $\mathrm{Fo}_{72}$ in HFSE-rich basalts, from $\mathrm{Fo}_{81}$ to $\mathrm{Fo}_{71}$ (with the majority of crystal cores in a narrow range at $\mathrm{Fo}_{77}$ to $\mathrm{Fo}_{78}$ ) in LKOT, and from $\mathrm{Fo}_{81}$ to $\mathrm{Fo}_{58}$ in arc-type basaltic andesite. Most olivine cores are close to equilibrium with their host rocks (Fig. 9). Yet, the basalt of the south flank, the pre-Cave Basalt, and tephra layer Bu2 contain olivine too Fo-rich, and some Cave Basalt lava flows have olivine too Fa-rich to be in equilibrium. $\mathrm{NiO}$ decreases relatively uniformly from about $0.3 \mathrm{wt} \%$ at $\mathrm{Fo}_{86}$ to $0.03 \mathrm{wt} \%$ at $\mathrm{Fo}_{60}$. In contrast to other mafic units, the pre-Cave Basalt
(LKOT group) and basalt of the south flank (HFSE-rich basalt group) that both erupted from the southern flank contain at least three populations of olivine (in order of abundance): normally zoned olivine $\left(\mathrm{Fo}_{87}-\mathrm{Fo}_{68}\right)$ with abundant Cr-spinel inclusions akin to olivine in HFSE-rich basalts, weakly zoned olivine $\left(\mathrm{Fo}_{79}-\mathrm{Fo}_{73}\right)$ with sparse spinel inclusions resembling olivine from the Cave Basalt (LKOT), and sparse reversely zoned crystals $\left(\mathrm{Fo}_{66}-\mathrm{Fo}_{74}\right)$.

\section{Chromian spinel}

Chromian spinel occurs as small inclusions (usually $<20 \mu \mathrm{m}$ ) in olivine crystals. These are abundant in olivine in HFSE-rich basalts, but rare in LKOT (Fig. 7a, e). Decreasing Fo contents in olivine are accompanied by an increasing titano-magnetite component in the spinel recognizable in higher Ti contents. Those with $\mathrm{TiO}_{2}>2 \mathrm{wt} \%$ are excluded from further discussion. This filter excludes spinel from the arc-type basaltic andesite of Nelson Glacier that does not preserve spinel from the earliest stages of crystallization. The most primitive spinels ( $\mathrm{Mg} \#>0.6$; $\mathrm{Mg} \#=\mathrm{Mg} /(\mathrm{Mg}+\mathrm{Fe})$ atomic ratio $)$ in $\mathrm{MSH}$ basalts have $\mathrm{Cr}$ numbers $(\mathrm{Cr} \#=\mathrm{Cr} /(\mathrm{Cr}+\mathrm{Al})$ atomic ratio $)$ ranging from 0.15 to 0.4 , similar to spinel from southern Washington LKOT and HFSE-rich basalts (Fig. 9b, c), but below 
Fig. 7 Backscattered electron images showing a glomerocrystic aggregate with weakly normally zoned plagioclase and olivine from the Cave Basalt (LKOT endmember), b-d reversely and complexly zoned plagioclase crystals from HFSE-rich basalts and basaltic andesites with sodic cores that are partly or completely resorbed and recrystallized. Some show alternating zones of internal normal zonation. Rims are normally zoned. e Olivine crystals with a thin Fa-rich rim and chromian spinel inclusions from HFSE-rich basalt, f olivine crystal with spinel inclusions rimmed by orthopyroxene from an arc-type basaltic andesite
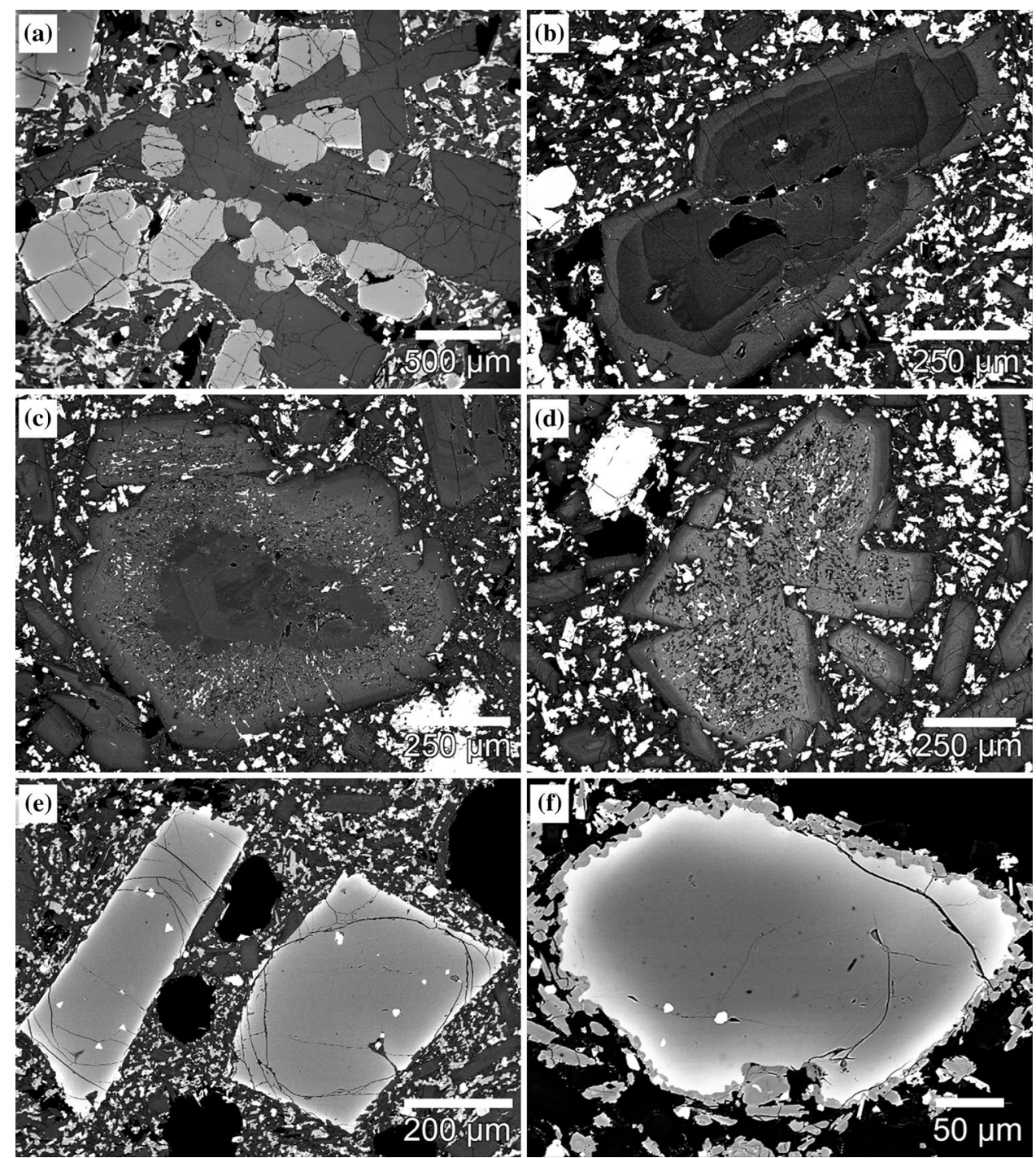

those of CAB ( $>0.4$, Baker et al. 1994; Clynne and Borg 1997; Smith and Leeman 2005). Spinel in MSH LKOT differs from southern Washington LKOT by slightly lower Cr\#s (0.15 vs. 0.20 at comparable Mg\#, Smith and Leeman $2005)$ and higher $\mathrm{V}_{2} \mathrm{O}_{3}$ concentrations (0.3-0.6 vs. $0.1-0.2$ wt\%, Smith and Leeman 2005).

The composition of primitive chromian spinel primarily depends on the lithology of the mantle source and the degree of melting, i.e., the $\mathrm{Cr}$-number decreases with source fertility and increases with the degree of melting (Arai 1994; Clynne and Borg 1997). Individual units form distinct trends on Cr\# vs. Fo plots (Fig. 9b) that project backwards to different lherzolite sources in the olivine spinel mantle array (OSMA, Arai 1994). Spinel Cr numbers in units of the HFSE-rich group weakly increase with decreasing Fo, whereas those in LKOT endmember (Cave Basalt) show a steep increase and have the lowest $\mathrm{Cr} \#(\mathrm{Cr} \#$ $=0.15$ ) in the most primitive (highest $\mathrm{Mg \# )}$ spinels. The
pre-Cave Basalt contains two populations of spinel, each following one of the trends.

\section{Constraints on intensive parameters}

\section{Temperature}

Magmatic temperatures of MSH basalts were calculated from the most primitive (spinel Mg\# > 60) olivine-spinel equilibrium pairs using the thermometer of Wan et al. (2008). Olivine with spinel inclusions is assumed to crystallize under near-liquidus conditions during transport and storage of magma in the crust. The highest temperatures $\left(1235-1310{ }^{\circ} \mathrm{C}, \pm 22{ }^{\circ} \mathrm{C}\right)$ are obtained for the LKOT endmember (bc). They overlap with temperatures $\left(1170-1270{ }^{\circ} \mathrm{C}\right)$ of the HFSE-rich endmember (bnf/Bu2) and other units of the HFSE-rich group $\left(1120-1280{ }^{\circ} \mathrm{C}\right)$ 

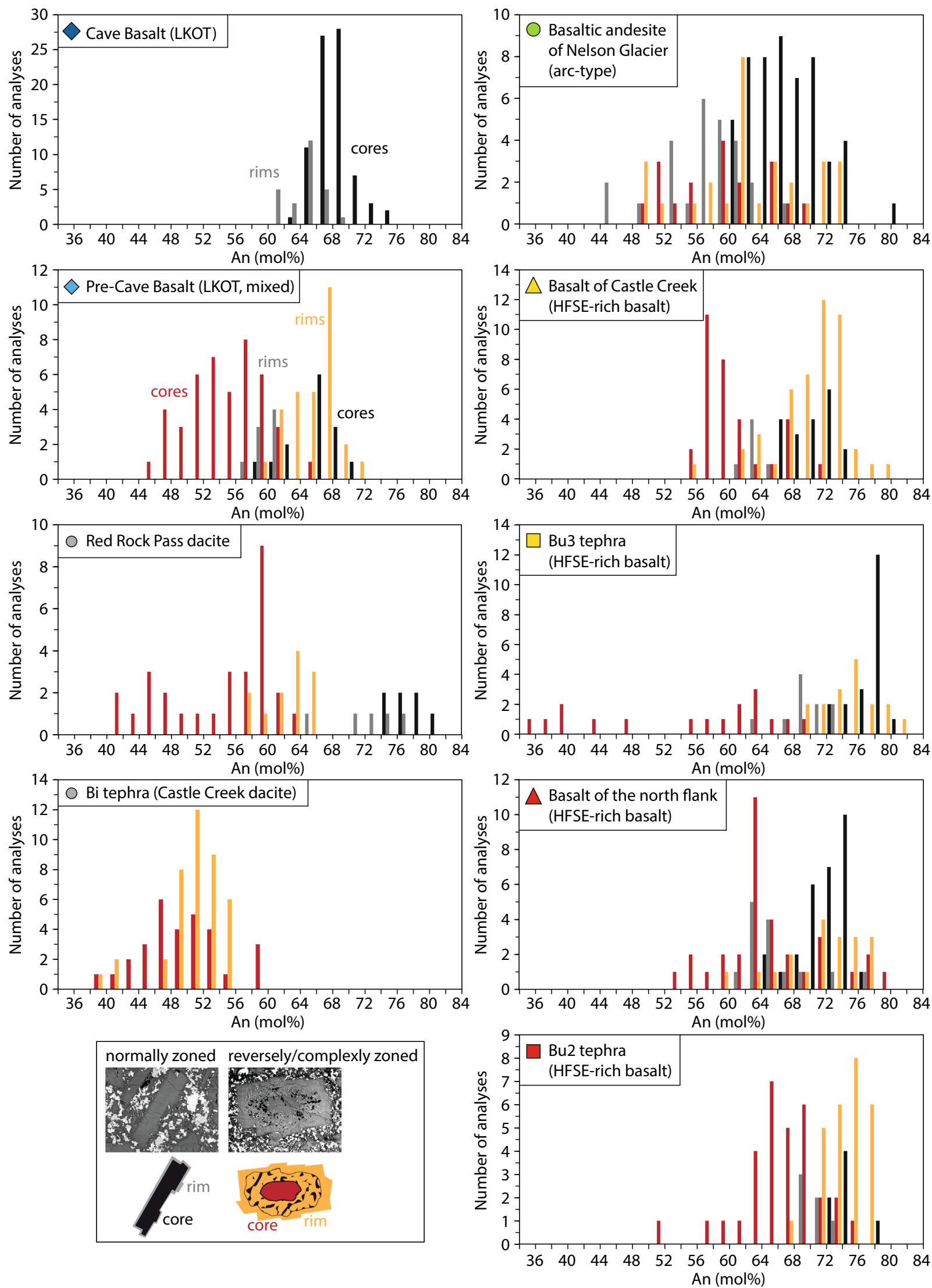
4Fig. 8 Histograms of anorthite (An) content in plagioclase comparing core and rim compositions of normally and reversely/complexly zoned crystals in different Castle Creek units. Units are shown in stratigraphic order from lower left to upper right. Normally zoned crystal cores overlap with rims of reversely zoned crystals

(Fig. 10a). Within most units, temperatures decrease with decreasing spinel Mg\#, consistent with progressive crystallization during cooling. As expected from the most primitive phases, temperatures calculated from olivine-spinel pairs exceed those derived from liquid, olivine-liquid, and plagioclase-liquid thermometers for LKOT (1203-1148 ${ }^{\circ} \mathrm{C}$ ) and HFSE-rich basalts $\left(1216-1112{ }^{\circ} \mathrm{C}\right)$ by Leeman and Smith (2018).

Storage temperatures just prior to eruption were derived from touching magnetite-ilmenite pairs in HFSE-rich $\mathrm{Bu}$ basalt tephra. Seven pairs that fulfilled the equilibrium conditions of Bacon and Hirschmann (1988) record temperatures from 850 to $1060{ }^{\circ} \mathrm{C}\left( \pm 50{ }^{\circ} \mathrm{C}\right.$, Sauerzapf et al. 2008). This range includes temperatures as low as observed in MSH dacites (Gardner et al. 1995a) and likely reflects some assimilation of evolved material in the mafic magma.

\section{Redox state}

The oxygen fugacity $\left(\mathrm{fO}_{2}\right)$ was determined using the olivine-spinel oxybarometer of Ballhaus et al. (1990) and temperatures from the same contiguous pairs. Olivine and spinel in the Cave Basalt (LKOT endmember) crystallized at an $\mathrm{fO}_{2}$ relative to the quartz-fayalite-magnetite (QFM) buffer of $\Delta \log \left(\mathrm{fO}_{2}\right)^{\mathrm{QFM}}=+0.1$ to +0.4 (average: $\mathrm{QFM}+0.2$ ). These conditions are slightly more reduced, but overlap in error $( \pm 0.4 \log$ units above QFM) with those of HFSE-rich basalts and basaltic andesites $\left(\Delta \log \left(\mathrm{fO}_{2}\right)^{\mathrm{QFM}}=+0.5\right.$ to +1.1 , average: $\mathrm{QFM}+0.8)$. More reduced conditions in LKOT are consistent with Fo contents in olivine (Fig. 9) below those expected from whole-rock equilibrium (due to stabilization of the $\mathrm{Fe}^{2+}$-component) as well as lower $\mathrm{Fe}^{3+}$ and higher $\mathrm{V}$ concentrations in spinel at a given $\mathrm{Mg \#}$. Melt $\mathrm{Fe}^{3+} / \Sigma \mathrm{Fe}$ ratios of $0.1-0.2$ estimated from the experimentally determined relationship between $\mathrm{Fe}^{2+} / \mathrm{Fe}^{3+}$ in spinel and coexisting melt using the method of Maurel and Maurel (1982) and Larsen and Pedersen (2000) confirm the relatively reduced character of MSH basalts.

\section{Water content}

Water contents in the mafic magmas of MSH are challenging to measure. Most of the units did not erupt explosively, precluding valuable estimates using melt inclusions. Olivine-hosted melt inclusions in two tephra layers of the HFSE-rich basalt group gave $\mathrm{H}_{2} \mathrm{O}$ contents up to $2 \mathrm{wt} \%$ (Rea et al. 2012). Yet, the LKOT and arc-type endmember did not erupt as tephras. The only other possible way of estimating $\mathrm{H}_{2} \mathrm{O}$ content in these units is mineral hygrometers. As those strongly rely on crystallization temperatures, which are poorly known, we estimated $\mathrm{H}_{2} \mathrm{O}$ contents from the $\mathrm{Ca}-\mathrm{Na}$ exchange between plagioclase and liquid (Sisson and Grove 1993). We used the most calcic plagioclase compositions from cores of normally zoned crystals and outer zones of reversely zoned crystals and whole-rock compositions as liquids. Ab-An exchange coefficients indicate equilibrium between selected plagioclases and their host rocks (Putirka 2008), as do calculated temperatures that overlap with plagioclase saturation temperatures within $5{ }^{\circ} \mathrm{C}$ (Putirka 2005). Comparison of plagioclase-whole-rock pairs with published partition coefficient $\left[(\mathrm{Ca} / \mathrm{Na})_{\mathrm{plg}} /(\mathrm{Ca} / \mathrm{Na})_{\text {liq }}\right]$ from Sisson and Grove (1993) suggests about $~ 1.8 \mathrm{wt} \% \mathrm{H}_{2} \mathrm{O}$ in LKOT, 3-4 wt $\% \mathrm{H}_{2} \mathrm{O}$ in HFSE-rich basalts, and 3.5-4 wt $\% \mathrm{H}_{2} \mathrm{O}$ in arc-type basaltic andesites (Fig. 10b).

Estimated water contents in HFSE-rich basalt tephras exceed those measured in melt inclusions, suggesting that melt inclusions might have been degassed prior to eruption and/or that the method we used slightly overestimates $\mathrm{H}_{2} \mathrm{O}$. Assimilation of some more evolved material could lead to an overestimation of the water content (e.g., assimilation of $15 \%$ of water-rich dacite could add up to about $0.5 \mathrm{wt} \%$ $\mathrm{H}_{2} \mathrm{O}$ ). Our estimates also exceed hygrometric estimates for MSH LKOT and HFSE-rich basalts by Leeman and Smith (2018). Using their approach of iterative calculation of pressure, temperature, and water content at a defined equilibrium plagioclase composition (for detailes see Leeman and Smith 2018), our samples yield $0.4-0.9 \mathrm{wt} \% \mathrm{H}_{2} \mathrm{O}$ in LKOT, negligible amounts of water in the HFSE-rich basalt endmember (bnf/Bu2), 0.3-1.3 wt\% $\mathrm{H}_{2} \mathrm{O}$ in other units of the HFSErich basalt group, and 2.0-2.4 wt\% in the arc-type basaltic andesite of Nelson Glacier. As arc-type basaltic andesites are not saturated with olivine (as required by the method), predicted temperatures in this unit are likely overestimated and water contents, respectively, underestimated. In addition, the equilibrium plagioclase composition defined by the method of Leeman and Smith (2018) is shifted to the sodic side of the spectrum embracing xenocrystic cores, which might further underestimate the water content. Combining evidence from the two methods suggests low-to-moderate $\mathrm{H}_{2} \mathrm{O}$ concentrations in LKOT and HFSE-rich basalts, and a range between 2 and $4 \mathrm{wt} \% \mathrm{H}_{2} \mathrm{O}$ in arc-type basaltic andesites.

\section{Discussion}

Throughout the past 40 years, various studies have discussed the diversity of primitive magmas in the Cascades; typically using radiogenic isotopes, experiments, reconstruction of primary melt compositions, and/or primitive minerals to characterize mantle source compositions (e.g., Bacon 1990; 

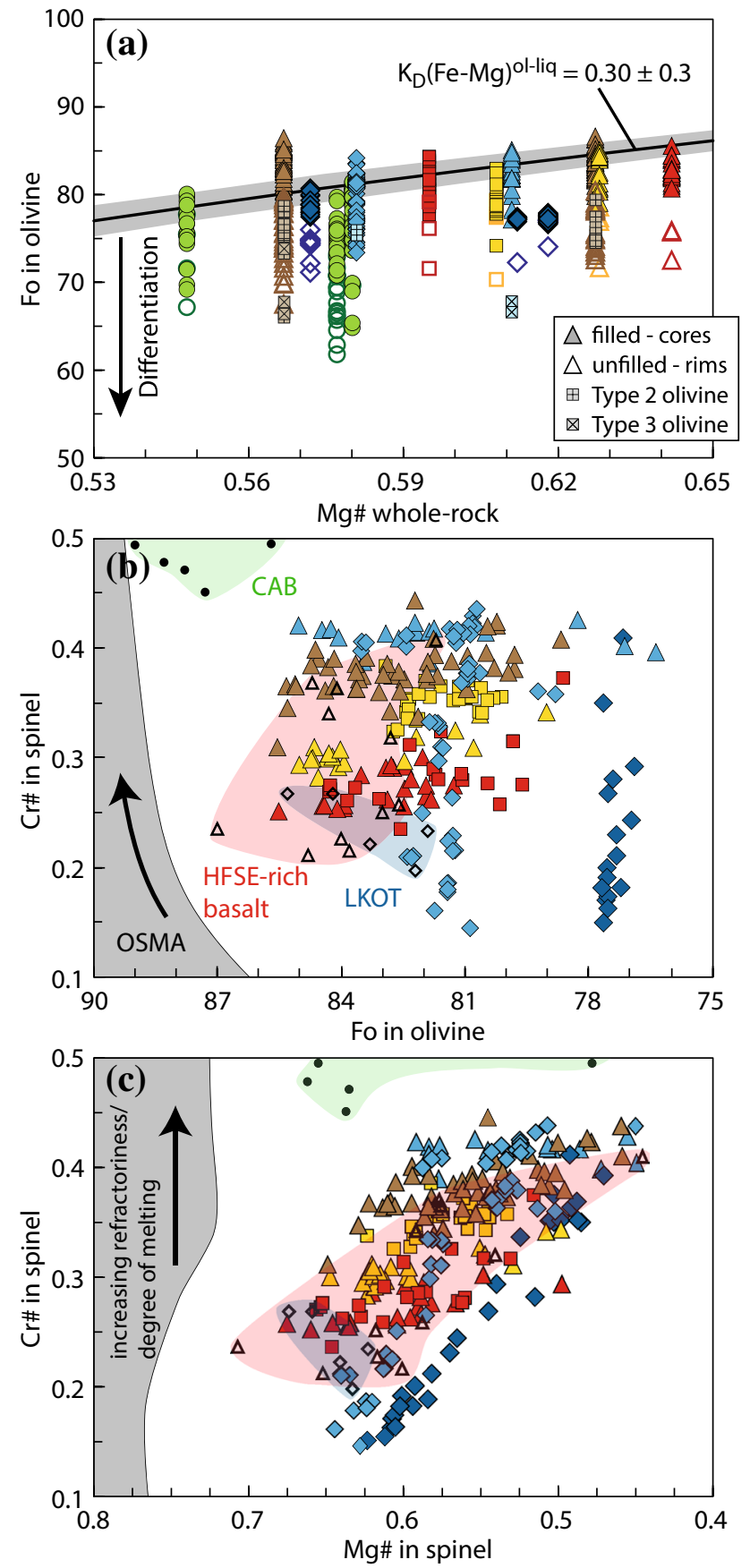

Fig. 9 Compositional variations in olivine and chromian spinel inclusions in different Castle Creek units. a Rhodes diagram showing the forsterite $(\mathrm{Fo})$ content of the olivine vs. $\mathrm{Mg} \#$ in whole-rock $(\mathrm{Mg} \#=\mathrm{Mg}$ / $\left(\mathrm{Mg}+\mathrm{Fe}^{2+}\right)$, calculated on a molar basis assuming $\mathrm{Fe}^{3+} / \Sigma \mathrm{Fe}=0.15$ for the Cave Basalt and 0.2 for all other mafic units). The equilibrium line refers to a $K_{\mathrm{D}}(\mathrm{Fe}-\mathrm{Mg})^{\text {ol-liq }}$ of $0.3 \pm 0.03$ (Putirka 2008). Filled symbols indicate crystal cores, unfilled symbols crystal rims. Sparsely occurring type 2 and 3 olivines in the pre-Cave Basalt and the basalt of the south flank are shown as crossed squares. b $\mathrm{Cr} \#[\mathrm{Cr} \#=\mathrm{Cr} /(\mathrm{Cr}+\mathrm{Al})]$ vs. $\mathrm{Fo}$ content of contiguous olivine-spinel pairs. The arrow in the olivine spinel mantle array (OSMA, Arai 1994) indicates increasing refractoriness of the mantle source and/or increasing degrees of partial melting. Colored fields show spinel compositions of southern Washington LKOT (open diamonds), HFSE-rich basalts (open triangles), and CAB (black points) of Smith and Leeman (2005). c Spinel Cr\# vs. Mg\#
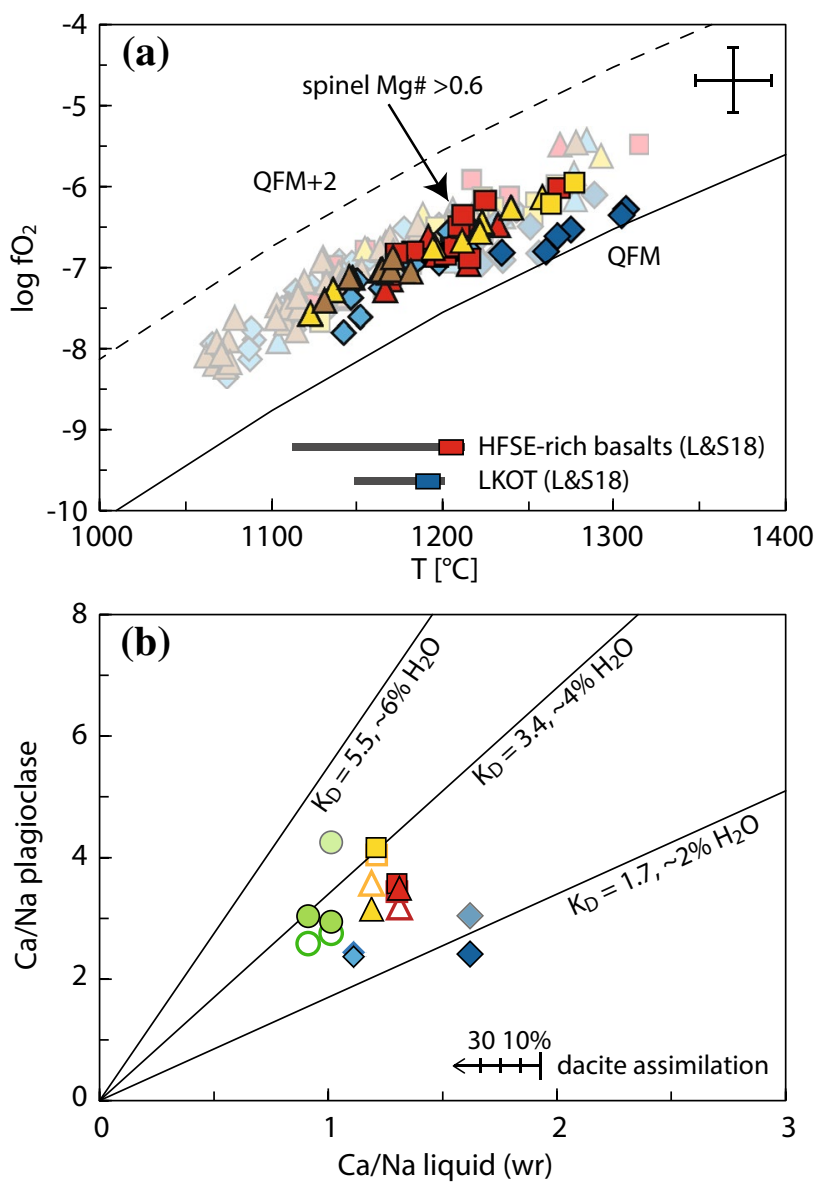

Fig. 10 a Oxygen fugacity ( $\left.\mathrm{fO}_{2}\right)$ vs. temperature (T) calculated from olivine-spinel pairs of different units (Ballhaus et al. 1990; Wan et al. 2008). Spinel with Mg\# < 0.6 is shown in opacity. Quartz-fayalitemagnetite (QFM) buffer curves are indicated for QFM (continuous line) and QFM + 2 (dashed line) (Frost 1991). Magmatic temperatures of the two basalt groups and their endmembers determined by different thermometers by Leeman and Smith (2018) are shown for comparison. b $\mathrm{Ca}-\mathrm{Na}$ exchange between plagioclase and liquid. $\mathrm{Ca} / \mathrm{Na}$ plagioclase is shown for the most calcic plagioclase composition in cores of normally zoned crystals (filled symbols) and in outer zones of reversely zoned crystals (empty symbols) of different units; outliers in two units are displayed in opacity. $\mathrm{Ca} / \mathrm{Na}$ liquid is taken from molar whole-rock (wr) compositions. An arrow illustrates the effect of dacite assimilation. Lines indicate experimental partition coefficients $\left(K_{\mathrm{D}}\right)$ from Sisson and Grove (1993) referring to 2, 4, and $6 \mathrm{wt} \%$ $\mathrm{H}_{2} \mathrm{O}$, respectively

Leeman et al. 1990, 2005; Bartels et al. 1991; Baker et al. 1994; Bacon et al. 1997; Borg et al. 1997; Clynne and Borg 1997; Conrey et al. 1997; Reiners et al. 2000; Grove et al. 2002; Smith and Leeman 2005; Hildreth 2007; Schmidt et al. 2008; Rowe et al. 2009; Moore and DeBari 2012; Mullen et al. 2017). These studies considered primitive magmas to have low phenocryst contents ( $<5 \%$, olivine \pm spinel), olivine compositions close to mantle values ( $\mathrm{Fo} \geq 86$ ), $\mathrm{Mg} \#$ $\geq 0.6, \mathrm{MgO}>8 \mathrm{wt} \%$, and high compatible trace-element contents $(\mathrm{Cr}>200 \mathrm{ppm}, \mathrm{Ni}>100 \mathrm{ppm})$ (Mullen et al. 2017). 
Mafic magmas of MSH deviate from these criteria by their high crystallinities (usually 10-30\%), abundant plagioclase crystals with disequilibrium textures and sodic cores in most basalts, several populations of olivine and spinel in some basalts, and their overall more evolved whole-rock $(\mathrm{MgO}$ 4.0-7.4 wt\%, Cr 40-240 ppm, and Ni 35-140 ppm) and mineral compositions ( $\mathrm{Fo} \leq 81-87)$ (Table 2). However, the most mafic endmembers still preserve their characteristic mantlederived signatures with strong compositional similarities to more primitive variants in the Cascades (Figs. 2, 3, 4, 5) as well as nearly primitive chromian spinel (Fig. 9b, c) allowing for some interpretation of their origin. In the following, we will discuss deviations from the endmember classification of the previous studies at MSH (Smith and Leeman 1993; Leeman and Smith 2018) and modifications of these non-primitive magmas by crustal processes, evaluate preexisting hypotheses on their mantle origin, and finally, discuss the implications for the MSH magma plumbing system.

\section{Three mafic endmembers at Mount St. Helens}

Despite its arc setting and the predominant eruption of hydrous dacites, true arc basalt did not erupt from MSH. The previous studies (Smith 1984; Leeman et al. 1990, 2005; Smith and Leeman 1993, 2005; Leeman and Smith 2018) also described LKOT and HFSE-rich basalt at $\mathrm{MSH}$. The origin of calc-alkaline basaltic andesites was predominantly attributed to mixing (Leeman and Smith
2018), similar to that of many andesites at MSH (Pallister et al. 1992; Smith and Leeman 1993). However, our third endmember (arc-type basaltic andesite) differs from previously described (low- $\mathrm{SiO}_{2}$ ) calc-alkaline basaltic andesites that form nearly continuous geochemical trends from LKOT and HFSE-rich basalts towards basaltic andesite. In contrast to these rocks, the newly described arc-type basaltic andesites are slightly more evolved, have lower contents of $\mathrm{FeO}, \mathrm{TiO}_{2}$, and $\mathrm{P}_{2} \mathrm{O}_{5}$, typical of Cascade $\mathrm{CAB}$ (Fig. 3), and show a pronounced arc signature (i.e., enrichment in fluid-mobile LILE and LREE relative to HFSE and HREE; Fig. 5; Table 2). Arc-type basaltic andesites show some disequilibrium textures, as expected from mafic magma crossing a silicic mush system, but at least in the basaltic andesite of Nelson Glacier (mng) these are minor (Appendix A5). This unit contains a single population of olivine with cores that are close to equilibrium with its whole-rock composition (Fig. 9a). In addition, it has lower concentration of $\mathrm{Nb}$ and strongly incompatible elements (e.g., $\mathrm{K}, \mathrm{Rb}, \mathrm{Ba}$, and $\mathrm{Ca}$ ) than Castle Creek andesites or dacites and has the highest $\mathrm{Al}_{2} \mathrm{O}_{3}$ content of Castle Creek rocks, both excluding a predominant mixing origin. The presence of melts with compositions similar to the basaltic andesite of Nelson Glacier at depth is further supported by equilibrium melts calculated from amphibole compositions (Wanke, unpublished data). These rocks are not primitive, but represent the most mafic endmember of the calc-alkaline rock series at MSH.
Table 2 Chemical characteristics of mafic endmembers from Mount St. Helens

\begin{tabular}{|c|c|c|c|}
\hline $\begin{array}{l}\text { Type } \\
\text { Unit }\end{array}$ & $\begin{array}{l}\text { HFSE-rich basalt } \\
\text { (bnf, Bu2) }\end{array}$ & $\begin{array}{l}\text { LKOT } \\
(\mathrm{bc})\end{array}$ & $\begin{array}{l}\text { Arc-type basaltic } \\
\text { andesite } \\
\text { (mng) }\end{array}$ \\
\hline Symbol & & & 0 \\
\hline $\mathrm{SiO}_{2} *(\mathrm{wt} \%)$ & $49.4-50.5$ & $49.6-51.1$ & $53.9-56.2$ \\
\hline $\mathrm{MgO}^{*}(\mathrm{wt} \%)$ & $6.4-7.4$ & $6.1-7.3$ & $4.0-4.9$ \\
\hline $\mathrm{K}_{2} \mathrm{O}^{*}(\mathrm{wt} \%)$ & $1.2-1.5$ & $0.5-0.7$ & $0.85-1.0$ \\
\hline $\mathrm{TiO}_{2} *(\mathrm{wt} \%)$ & $1.9-2.2$ & $1.4-1.7$ & $1.2-1.4$ \\
\hline $\mathrm{Ni}(\mathrm{ppm})$ & $80-141$ & $74-108$ & $34-52$ \\
\hline $\mathrm{Nb}$ (ppm) & $27-34$ & $6-9$ & $5-9$ \\
\hline $\mathrm{Sr}(\mathrm{ppm})$ & $580-680$ & $320-350$ & $485-505$ \\
\hline $\mathrm{La} / \mathrm{Yb}$ & $9.3-12.9$ & $3.8-4.1$ & $6.4-9.2$ \\
\hline $\mathrm{Dy} / \mathrm{Yb}$ & $2.0-2.3$ & $1.8-1.9$ & $2.0-2.3$ \\
\hline $\mathrm{Nb} / \mathrm{La}$ & $1.3-1.4$ & 0.8 & $0.5-0.7$ \\
\hline $\mathrm{Ba} / \mathrm{La}$ & $13.7-14.8$ & $14.3-15.0$ & $19.2-23.0$ \\
\hline Olivine & $\leq$ Fo85 & $\leq$ Fo81 & $\leq \mathrm{Fo} 81$ \\
\hline Spinel & $\mathrm{Mg} \# \leq 68$ & $\mathrm{Mg} \# \leq 63$ & $\mathrm{Mg} \# \leq 52$ \\
\hline Plagioclase & $\leq$ An78 & $\leq$ An75 & $\leq \mathrm{An} 75$ \\
\hline $\mathrm{T}\left({ }^{\circ} \mathrm{C}\right)^{\#}$ & $1170-1270$ & $1235-1310$ & \\
\hline$\Delta \log \left(\mathrm{fO}_{2}\right) \mathrm{QFM}^{\#}$ & +0.5 to +1.1 & +0.1 to +0.4 & \\
\hline
\end{tabular}

*Range includes data from compilation in Data Repository 5

${ }^{\#} \mathrm{~T}$ and $\mathrm{fO}_{2}$ calculated from olivine-spinel pairs using the methods of Wan et al. (2008) and Ballhaus et al. (1990) 


\section{Petrogenetic processes influencing the chemical composition of mafic endmembers}

\section{Fractional crystallization}

The high crystallinity of MSH basalts (10-30\%) and evidence for contamination prevents reconstruction of mantlederived melts. Yet, fractionation of olivine and spinel is evident from compositional trends formed by these minerals (Fig. 9). Weakly increasing Cr\# with decreasing Mg\# in most of the spinel is a function of decompression and crystallization of olivine ( \pm spinel), whereas the strong increase in spinel $\mathrm{Cr} \#$ with decreasing $\mathrm{Mg \#}$ in the Cave Basalt indicates that this compositional change was dominated by decompression rather than melt differentiation and/ or accompanied by co-crystallizing plagioclase (e.g., Clynne and Borg 1997; Smith and Leeman 2005). However, the lack of significant Eu anomalies in MSH basalt and basaltic andesite demonstrates that plagioclase was not a major early fractionating phase. Instead, it mostly crystallized late and has not significantly fractionated from the magma. Scattered $\mathrm{Eu} / \mathrm{Eu}^{*}(0.92-1.08)$ within some mafic units likely results from mineral proportions in the respective rock sample.

Trace-element variations exclude a genetic relationship between the mafic endmembers by fractional crystallization. HFSE-rich basalts have higher abundances of most incompatible trace elements than more evolved magmas (Figs. 4, 5). LKOT have similar abundances of HFSE and higher abundances of HREE than arc-type basaltic andesite. As incompatible elements would increase during fractionation, both basalt types can be excluded as parental magmas for arc-type basaltic andesites. Likewise, Leeman and Smith (2018) have shown that fractional crystallization cannot reproduce compositions of low- $\mathrm{SiO}_{2}$ basaltic andesites from HFSE-rich basalt or LKOT. Instead, they suggested that mixing between distinct primitive Cascade basalts and intermediate material similar to MSH andesite predominantly formed compositional trends from HFSE-rich basalt and LKOT towards low- $\mathrm{SiO}_{2}$ basaltic andesite.

\section{Assimilation and mixing in a polybaric mush column}

Isotopic, chemical, and textural characteristics of mafic magmas at $\mathrm{MSH}$ indicate interaction with various assimilants including pre-existing crustal lithologies and antecrystic material. The total isotopic variation between basalts and dacites is small, but significant $\left({ }^{87} \mathrm{Sr} /{ }^{86} \mathrm{Sr}=0.7030-0.7038\right.$, $\varepsilon_{\mathrm{Nd}}=7.7-4.4, \delta^{18} \mathrm{O}=5.7-6.8 \%$ ). The correlation of radiogenic $\mathrm{Sr}$ and $\mathrm{Nd}$ isotopes and with $\mathrm{SiO}_{2}$ (Fig. 6a, b) as well as an increase in $\delta^{18} \mathrm{O}$ above the array expected from closed-system fractionation (Fig. 6c, d) indicates that some crustal assimilation (assimilant with high ${ }^{87} \mathrm{Sr} /{ }^{86} \mathrm{Sr}$, low $\varepsilon_{\mathrm{Nd}}$, and high $\delta^{18} \mathrm{O}$ ) is involved during magma evolution. A quantitative interpretation of these isotope trends remains ambiguous owing to the unknown age of the (probably accretionary) lower crustal basement and the young (Tertiary) age of the upper crust (Hildreth 2007). The correlation of $\delta^{18} \mathrm{O}$ in olivine with whole-rock $\mathrm{SiO}_{2}$ suggests that some assimilation happens during early crystallization at depth.

Mafic magmas erupting in close spatial and temporal proximity with andesite and dacite at MSH would likely interact with pre-existing magmas or mush zones that plug the magmatic pathways. Most basalts and basaltic andesites contain plagioclase phenocrysts with sodic cores and/or various resorption textures (Fig. 7b-d) that represent relics of this process. Core compositions of reversely zoned plagioclase from $\mathrm{An}_{40}$ to $\mathrm{An}_{70}$ (in some cases down to $\mathrm{An}_{32}$; Fig. 8) are consistent with crystallization from andesitic to rhyolitic melts. The wide range in $\delta^{18} \mathrm{O}$ values of plagioclase separates with some values higher than those expected from closed-system fractionation, and hence, also large range in $\Delta^{18} \mathrm{O}_{\mathrm{plg}-\mathrm{ol}}$ (Fig. 6d) supports the chemical and textural evidences for assimilation of more evolved (higher $\delta^{18} \mathrm{O}$ ) material within the mafic magma. Other associated mineral phases from this crystal-rich dacite (e.g., amphibole \pm pyroxene \pm apatite \pm oxides) would have been unstable in the basaltic magmas and dissolved and/or partly re-equilibrated. This is supported by sparse, sometimes resorbed pyroxene and hornblende xenocrysts in some of the basalts and basaltic andesites. Furthermore, the wide range of temperatures recorded by $\mathrm{Fe}-\mathrm{Ti}$ oxides in Bu tephra $\left(1060-850{ }^{\circ} \mathrm{C}\right)$ that includes low temperatures as observed in $\mathrm{MSH}$ dacite indicates late stage assimilation of evolved material without time for equilibration of oxides. This observation is consistent with rare blebs of rhyolitic glass in basalt described by Smith and Leeman (1993) and Leeman and Smith (2018). Assimilation and mixing processes are exemplified by the eruption sequences on the southern and northern flanks of the volcano.

\section{Sequence of eruptions on the southern flank}

The sequence of eruptions on the southern flank well illustrates the interaction between different basalts and dacite in the upper crustal system. Evidence for mixing between distinct mafic endmembers is mostly absent, with exception of the pre-Cave Basalt (LKOT group) and the basalt of the south flank (HFSE-rich basalt group). The pre-Cave Basalt contains multiple populations of olivine and spinel (Fig. 9), respectively, similar to those of the basalt of the southern flank and the Cave Basalt (LKOT), and has compositions encompassing the high-K and low-K trends (Figs. 3, 4). Evidence for mixing between the two basalt groups is reinforced by the stratigraphic position of the pre-Cave Basalt between the Cave Basalt and the basalt of the south flank (Table 1). 
Sodic plagioclase cores in the pre-Cave Basalt represent relics of entrained more evolved material, but the basalt of the south flank is crystal poor (2-5\% crystals). Thus, it must have largely remelted the pre-existing crystal mush. That is supported by the preceding almost aphyric ( $<3 \%$ crystals) dacite of Red Rock Pass. It contains rare remnants of reversely zoned, almost completely resorbed plagioclase crystals and rare normally zoned crystals with basaltic core compositions $\left(\mathrm{An}_{82-72}\right.$, Fig. 8). These observations indicate strong heating and mixing between a basaltic and a dacitic component before eruption. The incoming basalt of the south flank might have heated the pre-existing dacite and forced it out of the shallow reservoir. Subsequently, the basalt ascended into the shallow reservoir that was mostly evacuated of magma allowing it to erupt crystal poor. The incoming Cave Basalt (LKOT) mixed with the residual basalt of the south flank (here basaltic andesite) to form the heterogeneous pre-Cave Basalt. This again cleared the conduit to allow the Cave Basalt magma to crystallize its characteristic assemblage of olivine and plagioclase with normal zoning and erupt almost unaffected by silicic magma.

\section{Sequence of eruptions on the northern flank}

Three magmatic cycles of dacite to andesite to basalt/ basaltic andesite similar to those first suggested by Hopson and Melson (1990) and discussed by Pallister et al. (1992) erupted on the northern and northeastern flanks of the volcano during the late Castle Creek period (Table 1). This cyclic behavior exemplifies how basalts pave their way through the upper crustal silicic reservoir. It is considered to be caused by basalt intrusion and mixing with resident dacite to produce andesite, followed by a less mixed olivine-bearing basaltic andesite, followed by basalt that retains sodic plagioclase cores as the only evidence for mixing (e.g., eruptive sequence a26-mtt-bnf, Appendix A5). The units in these cycles display decreasing phenocryst disequilibrium and $\mathrm{SiO}_{2}$ content as the cycle proceeds, producing the observed compositional trends from basaltic andesite to basalt. Eventually, part of the system is cleaned of intermediate compositions, which permits basalt to ascend with only minor interaction with the shallow system. Similarly, Leeman and Smith (2018) describe stratigraphic sequences of lava flows of single units (HFSE-rich basalts) that become progressively less evolved towards the top (upward increase in $\mathrm{Mg \#}$ ). Their calculations indicate that the compositional ranges observed in MSH LKOT and HFSE-rich basalts are dominantly caused by mixing of primitive Cascade basalts with different amounts of more evolved calc-alkaline material with compositions similar to MSH andesite. This interpretation is in agreement with our data.

\section{Origin of the mafic endmembers of Mount St. Helens}

The challenge in deciphering the origin of MSH basalts is to see through the contamination processes. Chromian spinel is the first crystallizing phase in most mafic magmas from MSH. It only crystallizes from relatively primitive liquids and, thus, is expected to crystallize before the melt was significantly affected by assimilation. Similar spinel compositions of genetically related basalts and peridotites (e.g., Dick and Bullen 1984) allow for some constraints on the mantle sources of the basalts. Spinel Cr\# increases, as the peridotite source becomes more refractory; i.e., harzburgite typically contains spinel with $\mathrm{Cr} \#>0.5$, whereas lherzolite has spinel with $\mathrm{Cr} \#<0.5$ (Arai 1994). Increasing degree of (hydrous) melting would further increase the Cr\#. The impact of other parameters, such as pressure, $\mathrm{fO}_{2}$, and fractionation or mixing, on the spinel Cr\# is usually less than a few percent (Clynne and Borg 1997). In addition to the investigation of primitive phases, striking geochemical similarities between the most mafic endmembers of each type and more primitive Cascade basalts (Figs. 3, 4, 5) allow for some further constraints on their origin.

\section{HFSE-rich basalts}

Each unit within the HFSE-rich basalt group contains chromian spinels with distinct compositions. They form almost linear trends caused by melt differentiation that allow for back projection to the OSMA (Fig. 9b, c) and indicate lherzolite mantle sources $(\mathrm{Cr} \#<0.4)$ for all units. Cr numbers in the most primitive spinels ( $\mathrm{Mg \#}>0.6)$ are lowest in the HFSE-rich endmembers, the basalt of the north flank (Cr\# = 0.25), and increase towards the basalt of Castle Creek (Cr\# $=0.3)$ and the basalt of the south flank ( $\mathrm{Cr} \#=0.35-0.4)$. As the effect of pressure, $\mathrm{fO}_{2}$, fractionation, or mixing on spinel compositions is too small to explain this variation in spinel Cr\# (Clynne and Borg 1997), the increase in $\mathrm{Cr} \#$ implies decreasing source fertilities and/or increasing degrees of melting. The HFSE-rich basalt endmember has the highest incompatible element concentrations (Figs. 3, 4,5 ) consistent with the lowest spinel $\mathrm{Cr} \#$ and the lowest degree of melting. Our data agree with the previous studies of HFSE-rich basalts in the Cascades that suggest an origin by low-degree partial melting (usually 1-5\%) of an enriched, fertile mantle source (Leeman et al. 1990, 2005; Bacon et al. 1997; Conrey et al. 1997; Reiners et al. 2000; Smith and Leeman 2005; Jicha et al. 2009; Rowe et al. 2009). Their steep REE patterns are usually assigned to residual garnet in the source. High $\mathrm{La} / \mathrm{Yb}(9.3-12.9)$ and $\mathrm{Dy} / \mathrm{Yb}(2.0-2.3)$ ratios (Fig. 11c, d; Table 2) in HFSE-rich basalts at MSH are consistent with an origin by low-degree melting in the stability field of garnet. 
Fig. 11 a $\mathrm{Ba} / \mathrm{Zr}$ vs. $\mathrm{Nb} / \mathrm{Zr}$, b $\mathrm{Ba} / \mathrm{Nb}$ vs. $\mathrm{Nb}$, c $\mathrm{Zr} / \mathrm{Nb}$ vs. $\mathrm{La} / \mathrm{Yb}, \mathbf{d} \mathrm{Zr} / \mathrm{Nb}$ vs. Dy/Yb. Symbols and colors as in Fig. 3. Note that $\mathrm{Zr} / \mathrm{Nb}$ and $\mathrm{La} / \mathrm{Yb}$ are plotted on log scales. The gray field in a indicates the compositional range of oceanic basalts from Leeman et al. (1990). Compositions from N-MORB, E-MORB and OIB after Sun and McDonough (1989) and the East Pacific Rise (EPR) (PetDB 2015) are shown for comparison
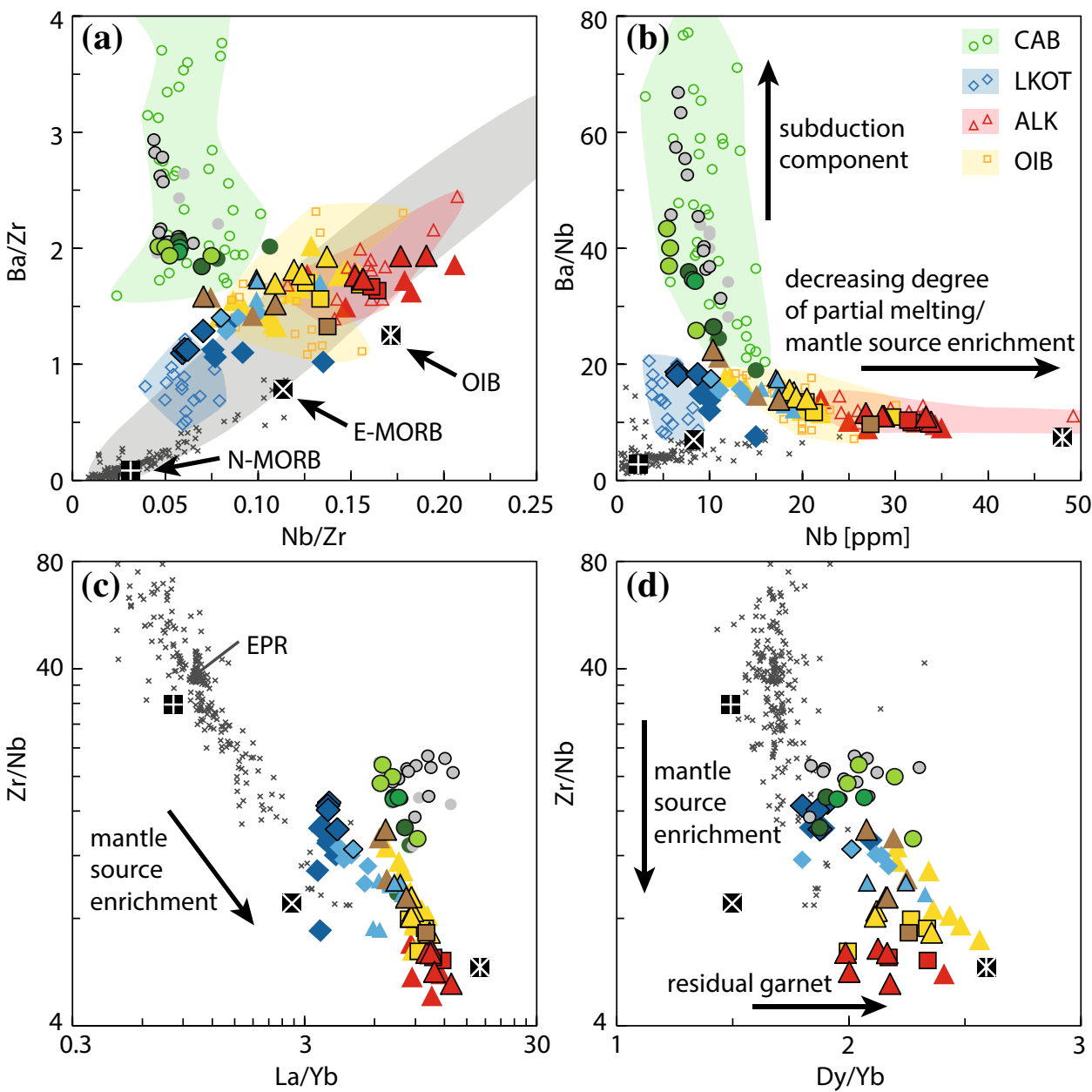

Spinel $\mathrm{Cr}$ numbers and trace-element abundances in whole rocks suggest variable contributions of a subduction component to different units of the HFSE-rich basalt group. Low water contents (up to $2 \mathrm{wt} \% \mathrm{H}_{2} \mathrm{O}$ in olivinehosted melt inclusions in Bu2 and Bu3 tephra; Rea et al. 2012), high magmatic temperatures (Fig. 10), and the lack of a pronounced arc signature in these rocks (Fig. 5) imply comparably dry conditions during melting. Yet, Cr numbers in the most primitive spinels of the basalt of the south flank nearly approach those of Cascade CAB (Fig. 9b, c) implying higher degrees of partial melting and a potentially greater subduction component. They are inversely correlated with $\mathrm{Nb}$ and $\mathrm{Nb} / \mathrm{La}$ that decrease (at comparable $\mathrm{MgO}$ ) from the basalt of the north flank to the basalt of Castle Creek to the basalt of the south flank (Figs. 4, 5) supporting an increasing (albeit minor) subduction component in these units. Such an interpretation is consistent with studies that suggest a correlation between the degree of melting and the addition of a slab-derived component in Cascade basalts (Borg et al. 1997; Reiners et al. 2000; Rowe et al. 2009).

\section{LKOT}

Spinel in LKOT from MSH has low Cr numbers $(\mathrm{Cr} \#=$ 0.15 at highest Mg\#, Fig. 9c) indicative of a highly fertile (i.e., rich in $\mathrm{Al}, \mathrm{Ca}$, and $\mathrm{Fe}$, high capability to produce melt, Clynne and Borg 1997) lherzolite source, consistent with comparably high contents of $\mathrm{Al}, \mathrm{Ca}$, and $\mathrm{Fe}$ in whole rocks (Fig. 3). Although high $\mathrm{Ca}$ and $\mathrm{Al}$ can also result from accumulation of plagioclase (which is abundant in glomerocrysts in the Cave Basalt), low $\mathrm{Sr}$, and the lack of a Eu anomaly in LKOT as well as high $\mathrm{Ca}$ and $\mathrm{Al}$ in more primitive Cascade LKOT suggest that this signature is rather a source characteristic than the result of crystal accumulation. The most primitive spinels in LKOT have lower $\mathrm{Cr}$ numbers $(\mathrm{Cr} \#=0.15)$ than those in HFSE-rich basalts $(\mathrm{Cr} \#$ $=0.25-0.4$ ) pointing to a more fertile source and/or lower degrees of melting in LKOT (Fig. 9c, d). Both are inconsistent with lower abundances of incompatible trace elements in LKOT that require a more trace-element-depleted source and/or higher degrees of melting (Fig. 11b). This discrepancy indicates that MSH LKOT must be derived from a 
compositionally different (less enriched) lherzolite source than HFSE-rich basalts.

Slight enrichments in LREE and LILE over HREE and HFSE (Figs. 5, 12) point a weak subduction component in MSH LKOT. As good constraints on water contents in
MSH LKOT are lacking, it remains speculative whether this signature represents a recent subduction component or was inherited in the source during ancient subduction times. Hygrometric estimates of water content suggest up to $1.8 \mathrm{wt} \% \mathrm{H}_{2} \mathrm{O}$ in the Cave Basalt (Fig. 10b), illustrating that
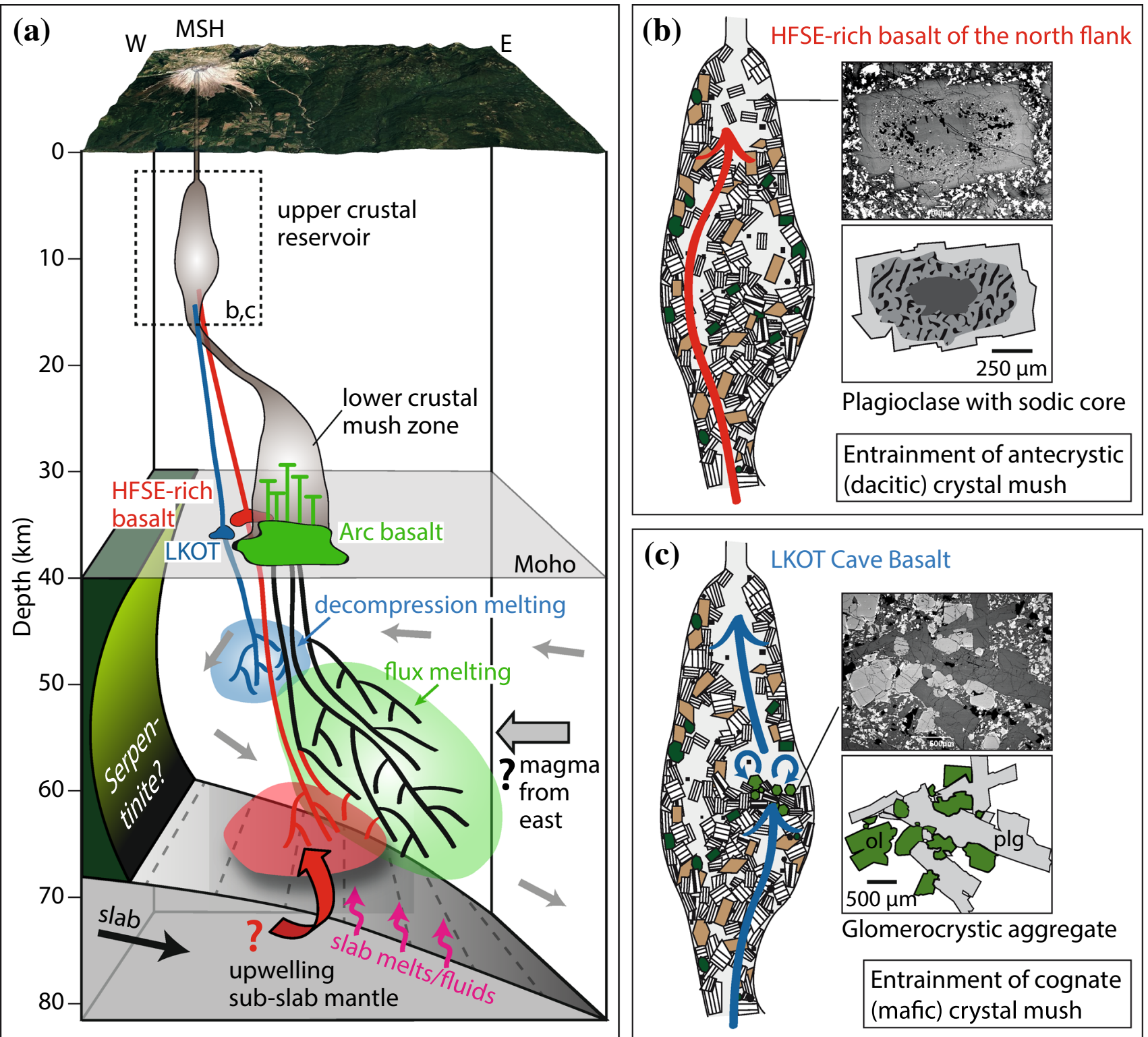

Fig. 12 a Perspective view of the proposed magmatic plumbing system of MSH with the three basalt types derived from different mantle sources. Hydrous arc basalts are generated by flux melting in the mantle wedge, whereas HFSE-rich basalt derived from the (waterpoor) periphery of the main melting column, potentially tapping an enriched source. LKOT derived by decompression melting from a fertile lherzolite source in the uppermost mantle. Note that the spatial distribution of mantle sources is schematic and remains speculative. Arc basalts predominantly feed the lower crustal mush zone, while peripheral LKOT and HFSE-rich basalts bypass the main lower crustal plumbing system. Crust and mantle geometry is based on Parsons et al. (1999) and McCrory et al. (2012). The positions of the magma reservoirs are inferred from seismic low velocity zones (Kiser et al. 2016). The outline of the upper crustal magma reservoir is taken from Scandone and Malone (1985) and Pallister et al. (2008). The serpentinized mantle wedge and magma transport into the wedge from further east is shown as suggested by Hansen et al. (2016). b Schematic cross-section through the upper crustal magma reservoir illustrating the entrainment of antecrystic material into the HFSE-rich basalt of the north flank, and $\mathbf{c}$ entrainment of cognate crystal mush into the Cave Basalt (LKOT) after the pathway was cleaned by preceding basalts. The upper crustal mush is pictured as plagioclase (white, striped), amphibole (brown), pyroxene (green), oxides (black), and melt (light gray) 
some contribution of a recent subduction component may be reasonable. However, high magmatic temperatures (up to $1300{ }^{\circ} \mathrm{C}$, Fig. 10a) and comparatively reduced conditions (around QFM + 0.2) in MSH LKOT require low water contents and high crustal pressure during early crystallization of olivine and spinel, suggesting that our water contents are likely overestimated for LKOT. That is further supported by nearly anhydrous conditions suggested from experiments (Bartels et al. 1991) and olivine-hosted melt inclusions (Sisson and Layne 1993; Le Voyer et al. 2010) in southern Cascade LKOT. These are generally interpreted as dry, decompression-induced melts (Leeman et al. 1990, 2005; Bartels et al. 1991; Bacon et al. 1997; Elkins-Tanton et al. 2001), derived by $6-10 \%$ of partial melting in the Mt. Shasta region (Baker et al. 1994) and from $<10 \%$ in the northern to $20-30 \%$ in the southern central Cascades (Conrey et al. 1997). Along with the previous interpretations and the position of MSH in an extensional regime (Weaver et al. 1987), we interpret our data to reflect an origin of MSH LKOT by dominantly decompression-induced melting of a fertile lherzolite source. The lack of HREE depletion in LKOT (Fig. 5; Table 2) is consistent with a garnet-free source in the upper mantle.

\section{Arc-type basaltic andesites}

As arc-type basaltic andesites at MSH contain only 3.9-5.2 $\mathrm{wt} \% \mathrm{MgO}$ and lack primitive spinel, a mantlederived parent remains poorly constrained. A direct mantle origin of these basaltic andesites, as suggested for primitive high-Mg basaltic andesites in the Shasta and Lassen regions (Baker et al. 1994; Clynne and Borg 1997; Conrey et al. 1997; Grove et al. 2002) or for some non-primitive variants at Mt. Baker and Glacier Peak (Moore and DeBari 2012; Mullen and McCallum 2014; Sas et al. 2017), can be excluded based on their comparably evolved whole-rock and mineral compositions (Fo $\leq 81$ in olivine, An $\leq 75$ in plagioclase). Along with the chemical subduction signature and high estimated water contents, these characteristics rather suggest a derivation by differentiation of a CAB-like precursor, as observed in other places in the Cascades (e.g., Kinzler et al. 2000; Hildreth 2007; Moore and DeBari 2012).

Arc-type basaltic andesites at MSH show a pronounced arc signature with enrichment in fluid-mobile over immobile trace elements and negative $\mathrm{Nb}-\mathrm{Ta}$ anomalies (Figs. 5, 11; Table 2), yet the origin of such compositions in Cascade basalts is still debated. Most studies agree upon an origin of Cascade $\mathrm{CAB}$ and BA by flux melting ( $10-30 \%$ partial melting) of a variably depleted mantle source (Bacon et al. 1997; Reiners et al. 2000; Grove et al. 2002; Hildreth 2007; Rowe et al. 2009; Moore and DeBari 2012; Mullen et al. 2017). That is confirmed by olivine-hosted melt inclusions with water contents up to $3.6 \mathrm{wt} \%$ (Sisson and Layne
1993; Le Voyer et al. 2010; Ruscitto et al. 2010) and experimental constraints on southern Cascade CAB (Baker et al. 1994). In contrast, Leeman et al. (2004) and Leeman et al. (2005) concluded from estimated mantle segregation pressures and temperatures and the depletion of light volatile B and $\mathrm{Li}$ in southern Washington basalts that the young and hot slab almost completely dehydrates beneath the forearc. Consequently, they proposed that partial melting in the mantle wedge is dominantly dry and the subduction signature in $\mathrm{CAB}$ and $\mathrm{BA}$ could be inherited from a mantle source metasomatized during ancient stages of Cascade subduction. However, depletion of light volatile B is also observed in the Lassen (Walowski et al. 2016) and Shasta regions (Rose et al. 2001; Le Voyer et al. 2010) of the arc; nevertheless, those basalts contain significant hydrous slab components. Walowski et al. (2016) explained this discrepancy with a fluid source in the sub-slab mantle rather than in the slab itself, which might also be the case in the southern Washington area.

The distinction between an origin of the subduction signature in MSH arc-type basaltic andesites from recent flux melting or from an ancient subduction component stored in the mantle requires the knowledge of water content. Plagioclase hygrometry suggests between 2 and $4 \mathrm{wt} \% \mathrm{H}_{2} \mathrm{O}$. We argue that the upper end is more likely, because these basaltic andesites have high $\mathrm{Al}_{2} \mathrm{O}_{3}$ and low $\mathrm{FeO}$ and $\mathrm{TiO}_{2}$ compared to other mafic units at MSH (Fig. 3), supporting higher water contents in these rocks. Crystallization under hydrous conditions leads to the suppression of plagioclase and early appearance of $\mathrm{Fe}$-Ti oxides in the crystallizing mineral assemblage, resulting in higher $\mathrm{Al}_{2} \mathrm{O}_{3}$ and lower $\mathrm{FeO}$ and $\mathrm{TiO}_{2}$. In addition, the presence of a hydrous mafic endmember is supported by water contents up to 6-7 wt\% in MSH dacites (Gardner et al. 1995b; Blundy and Cashman 2005; Blundy et al. 2008). Blatter et al. (2017) have shown by mass-balance calculations based on experiments on MSH dacite that regular recharge of the system by $\mathrm{H}_{2} \mathrm{O}$-rich basalt or basaltic andesite is necessary to induce persistent production of hydrous dacite liquid in the mid to lower crust. Thus, we interpret arc-type basaltic precursors of these magmas to result from flux melting of a peridotite source. As primitive compositions are not preserved, it is not possible to determine whether this source is distinct from those of LKOT or HFSE-rich basalt or affected by a greater contribution of a hydrous slab-derived component. Comparably high abundances of (even fluid immobile) trace elements indicate that all basalt types at MSH derived from mantle sources more enriched than that of N-MORB (Figs. 5, 11).

\section{Heterogeneity of the mantle}

The heterogeneity of mantle sources beneath MSH is at least partly caused by the accretionary history of the arc. 
The oceanic Siletzia terrane accreted about $50 \mathrm{Ma}$ ago to the North American border (Wells et al. 2014), likely influencing the oceanic affinity (including OIB- and E-MORBlike rocks) of many Cascade basalts. In addition, upwelling asthenospheric mantle, as suggested as a source for HFSErich basalts in the Mt. Adams-Simcoe back-arc region (Mullen et al. 2017), might contribute to the heterogeneity in the mantle wedge (Fig. 12a). Indeed, seismic tomography indicates a gap or tear in the slab beneath northern Oregon providing a potential pathway for upwelling enriched sub-slab mantle (Schmandt and Humphreys 2010; Martin-Short and Allen 2013). Alternatively, Hansen et al. (2016) suggested that the melt source region lies east towards Mt. Adams and migrates into the mantle beneath MSH.

The close spatial and temporal eruption of different mafic endmembers (within $<5 \mathrm{~km}$ and 150 years) at MSH requires simultaneous tapping of different mantle sources and different melting mechanisms acting over short distances. This is of particular interest, as the slab reaches only a depth of about $70 \mathrm{~km}$ beneath MSH (McCrory et al. 2012), just approaching the depth range of hydrous mineral breakdown and water release (Schmidt and Poli 1998). LKOT and HFSE-rich basalts derived from at least two distinct, variably trace-element-enriched, fertile lherzolite sources. Their origin is dominated by decompression melting with only minor contributions of a subduction component. In addition, CAB-like precursors of arc-type basaltic andesites are derived by flux melting from a similar or an additional mantle source. According to the limited space in the mantle wedge and the evidence for variable (although minor) amounts of subduction components in different units of the HFSE-rich basalt group, these likely derived from the waterpoor periphery of the main flux melting regime, potentially tapping an enriched source (Fig. 12a).

\section{Implications for the Mount St. Helens magma plumbing system}

\section{Ascent through the crust}

The close temporal and spatial eruptions of different basalt types, andesites and dacites have important implications for the geometry of the MSH magma plumbing system. When associated with intermediate to silicic stratovolcanoes, basalts are typically restricted to the periphery of these systems (e.g., Hildreth 2007). The reasons are mush zones in the crust that induce a shadow zone on the surface. They form rheological and lithological barriers that intercept ascending denser mafic magmas (Dufek and Bergantz 2005; Karlstrom et al. 2009; Kent et al. 2010). Yet, at MSH, true basalt erupted trough the axial system. Some vents of the basalt of the north flank are directly associated with dacitic lava domes (e.g., Dogs Head dome) and some dykes of the basalt of Castle Creek are observed in the 1980 crater walls. The apparent lack of a shadow effect suggests that some basalts might largely bypass the major plumbing system. Recent seismic investigations indicate a high velocity zone in the lower crust vertically beneath MSH and a low velocity zone about $10-20 \mathrm{~km}$ southeast of the volcano; the latter interpreted as a lower crustal storage zone with dispersed melt (Kiser et al. 2016). Magnetotelluric data further supports the location of a lower crustal mush zone east of MSH (Bedrosian et al. 2018). Such an offset geometry of the magmatic system (Fig. 12a) facilitates the upward migration of basalt aside from main lower crustal plumbing system and agrees with the simultaneous generation of dacites in a mid to lower crustal mush zone (at about 700-900 MPa, Blatter et al. 2017).

Different mafic units have distinct chromian spinel compositions and show variations in source fertility and/or degree of partial melting (Fig. 9b, c). Thus, they require extraction from the mantle and ascent through the crust as individual batches of magma (except from the mixed pre-Cave Basalt). Models of dynamic melt transport in the mantle suggest that melts are transported in a network of channels that converge close to the base of the crust (e.g., Kelemen et al. 1997; Spiegelman and Kelemen 2003). Channelized transport allows for the concurrent existence of variable melt compositions in a restricted area; potentially leading to peripheral channels transporting compositionally different (e.g., water-poorer) melts. Although much of that melt might get absorbed by the lower crustal mush zone or freeze during transport, some would eventually be extracted from marginal melt channels aside from the main focus region of the channel network, facilitated by the proposed offset geometry of the plumbing system (Fig. 12a) (Kiser et al. 2016). Weak crustal zones associated with the fracture system beneath MSH (Weaver et al. 1987) might then serve as conduits for fast and nearly isolated transport of individual magma batches that prevents them from mixing, stalling, and freezing in the crust. That is consistent with the common occurrence of different basalt types associated with fracture systems in the Cascades (e.g., Leeman et al. 1990; Hildreth 2007; Muffler et al. 2011).

\section{Interaction with the shallow crustal system}

Geochemical mixing trends from basalt to basaltic andesite within individual units as well as relics of more evolved material illustrate the interaction of basalt with the upper crustal part of the system. Distinct compositions of entrained plagioclase cores in individual mafic units indicate that the ascending magmas assimilate variably evolved magma/mush on their way to the surface (e.g., the pre-Cave Basalt contains more evolved plagioclase cores than the basalt of the north flank, Fig. 8). This observation indicates that different 
units take individual pathways through the upper crustal reservoir, while tapping compositionally different (more evolved), melt-rich regions (Fig. 12b, c). This interpretation is consistent with recent seismic imaging that shows accumulation of melt (up to 10-12 vol\%) in laterally dispersed, vertically interconnected lenses within a mush-filled reservoir (Kiser et al. 2018), although the geometry might have been slightly different during Castle Creek time.

The difficulty of crossing this mush-filled reservoir is illustrated by the restriction of basalt eruptions to a short interval during the Castle Creek period (1700-1900 B.P.). Except for olivine-bearing mafic inclusions in a Cougar age (18-28 ka B.P.) lava flow and olivine-bearing Mo tephra (Clynne et al. 2008), there is evidence for mafic magma (in form of mafic inclusions) in the shallow magmatic system from 2.6 to $0.2 \mathrm{ka}$ (from Pine Creek to Kalama eruptive periods). The reason for the sudden appearance of basaltic magma in the shallow magma system from Pine Creek to Kalama times remains speculative. There is no supporting evidence for a change in the crustal stress field in the MSH area or a major edifice collapse during Pine Creek time, as proposed for the initiation of basaltic volcanism at similar systems (e.g., South Soufrière Hills, Cassidy et al. 2015). However, in agreement with the location of MSH along a tensional pull-apart basin associated with an offset in the St. Helens seismic zone (Weaver et al. 1987), it seems likely that a change in the crustal stress regime (such as an extensional tectonic event leading to re-activation of old fracture zones) enabled basalts to reach shallow crustal levels.

\section{Conclusions}

Detailed chemical and petrological investigations of eight mafic units from MSH that erupted during a short interval at the end of the Castle Creek period (1900-1700 years B.C.) reveal three mafic endmembers including HFSE-rich basalts, LKOT and arc-type basaltic andesites, each resembling more primitive variants in the Cascades. Some of the heterogeneity in mafic compositions clearly results from fractional crystallization, magma mixing, and assimilation of old crustal and young more evolved calc-alkaline material at different depths. However, the variability of the most mafic endmembers still requires at least two distinct mantle sources and different contributions from a slab-derived component.

The close temporal and spatial eruption of three mafic endmembers at MSH indicates simultaneous tapping of different sources on relatively small scales. LKOT and HFSErich basalts derived dominated by decompression melting from at least two distinct fertile lherzolite sources. Both are weakly affected by a subduction component. In contrast, arc-type basaltic andesites likely represent differentiation products of hydrous arc basalt (that did not erupt) generated by flux melting in the mantle. Our data are consistent with a formation of HFSE-rich basalts in the water-poor periphery of the main melting column (potentially tapping an enriched source, Figs. 11, 12a). In those regions, water contents and degrees of melting are low(er), leading to higher concentrations of incompatible elements. Weak crustal zones associated with the old fracture system beneath MSH (Weaver et al. 1987) likely provide conduits for rapid ascent of individual batches of magma and prevent them from freezing in the crust and hybridization.

The compositional diversity of magmas erupted during the Castle Creek eruptive period of MSH requires repeated injection of mafic magma into the shallow magmatic system. The lack of a shadow zone at MSH (i.e., basalts and basaltic andesites erupt through the axial system) that is typically observed at other andesitic-to-dacitic stratovolcanoes in the Cascades (Hildreth 2007) may be caused by an offset plumbing system, as proposed by seismic tomography (Kiser et al. 2016). Such geometry would facilitate basalt ascent aside from the lower crustal mush zone, before they merge with the upper crustal reservoir, interact with resident dacite, crystallize, and gain their characteristic petrographic appearance (Fig. 12). Conspicuous geochemical trends from the two basaltic endmembers towards basaltic andesite are predominantly caused by assimilation of more evolved calcalkaline material. Sodic plagioclase cores and rare resorbed mafic minerals in most of the basalts and basaltic andesites form relics of this process.

Acknowledgements We thank Lydia Zehnder, Marcel Guillong and Markus Waelle for laboratory assistance during XRF and laser analyses. We appreciate constructive comments from Ben Ellis, Jon Blundy, Sue DeBari, Bill Leeman, Othmar Müntener, and an anonymous reviewer on earlier versions of this manuscript that helped clarify our ideas. This project has been supported by Swiss National Science Foundation grant 200021_146268. Any use of trade, firm, or product names is for descriptive purposes only and does not imply endorsement by the U.S. Government.

\section{References}

Arai S (1994) Characterization of spinel peridotites by olivine-spinel compositional relationships: review and interpretation. Chem Geol 113(3-4):191-204

Bacon CR (1990) Calc-alkaline, shoshonitic, and primitive tholeiitic lavas from monogenetic volcanoes near Crater Lake, Oregon. J Petrol 31(1):135-166

Bacon RC, Hirschmann MM (1988) Mg/Mn partitioning as a test for equilibrium between coexisting Fe-Ti oxides. Am Mineral 73:57-61

Bacon CR, Bruggman PE, Christiansen RL, Clynne MA, DonnellyNolan JM, Hildreth W (1997) Primitive magmas at five Cascades volcanic fields: melts from hot, heterogeneous sub-arc mantle. Can Mineral 35:397-424

Baker MB, Grove TL, Price R (1994) Primitive basalts and andesites from the Mt. Shasta region, N. California: products 
of varying melt fraction and water content. Contrib Mineral Petrol 118(2):111-129

Ballhaus C, Berry RF, Green DH (1990) Oxygen fugacity controls in the Earth's upper mantle. Nature 348(6300):437-440

Bartels KS, Kinzler RJ, Grove TL (1991) High pressure phase relations of primitive high-alumina basalts from Medicine Lake volcano, northern California. Contrib Mineral Petrol 108(3):253-270

Bedrosian PA, Peacock JR, Bowles-Martinez E, Schultz A, Hill GJ (2018) Crustal inheritance and a top-down control on arc magmatism at Mount St. Helens. Nat Geosci 11:865-870

Bindeman IN (2008) Oxygen isotopes in mantle and crustal magmas as revealed by single crystal analysis. Rev Mineral Geochem 69:445-478

Blatter DL, Sisson TW, Hankins WB (2017) Voluminous arc dacites as amphibole reaction-boundary liquids. Contrib Mineral Petrol 172(5):27

Blundy JD, Cashman KV (2005) Rapid decompression-driven crystallization recorded by melt inclusions from Mount St. Helens volcano. Geology 33(10):793-796

Blundy JD, Cashman KV, Berlo K (2008) Evolving magma storage conditions beneath Mount St. Helens inferred from chemical variations in melt inclusions from the 1980-1986 and current (2004-2006) eruptions. In: Sherrod DR, Scott WE, Stauffer PH (eds) A volcano rekindled: the renewed eruption of Mount St Helens, 2004-2006, USGS Prof Pap 1750, pp 755-790

Borg LE, Clynne MA, Bullen TD (1997) The variable role of slabderived fluids in the generation of a suite of primitive calcalkaline lavas from the southernmost cascades, Calilornia. Can Mineral 35:425-452

Cassidy M, Watt S, Talling P, Palmer M, Edmonds M, Jutzeler M, Wall-Palmer D, Manga M, Coussens M, Gernon T (2015) Rapid onset of mafic magmatism facilitated by volcanic edifice collapse. Geophys Res Lett 42(12):4778-4785

Chiba H, Chacko T, Clayton RN, Goldsmith JR (1989) Oxygen isotope fractionations involving diopside, forsterite, magnetite, and calcite: application to geothermometry. Geochim Cosmochim Acta 53(11):2985-2995

Claiborne LL, Miller CF, Flanagan DM, Clynne MA, Wooden JL (2010) Zircon reveals protracted magma storage and recycling beneath Mount St. Helens. Geology 38(11):1011-1014

Clynne MA, Borg LE (1997) Olivine and chromian spinel in primitive calc-alkaline and tholeiitic lavas from the southernmost Cascade range, California: a reflection of relative fertility of the source. Can Mineral 35:453-472

Clynne MA, Calvert AT, Wolfe EW, Evarts RC, Fleck RJ, Lanphere MA (2008) The Pleistocene eruptive history of Mount St. Helens, Washington, from 300,000 to 12,800 years before present. In: Sherrod DR, Scott WE, Stauffer PH (eds) A volcano rekindled: the renewed eruption of Mount St Helens, 20042006, USGS Prof Pap 1750, pp 593-627

Conrey RM, Sherrod DR, Hooper PR, Swanson DA (1997) Diverse primitive magmas in the Cascade arc, Northern Oregon and Southern Washington. Can Mineral 35(2):367-396

Crandell DR (1987) Deposits of pre-1980 pyroclastic flows and lahars from Mount St. Helens volcano, Washington. USGS Prof Pap 1444

Dick HJB, Bullen T (1984) Chromian spinel as a petrogenetic indicator in abyssal and alpine-type peridotites and spatially associated lavas. Contrib Mineral Petrol 86(1):54-76

Dufek J, Bergantz GW (2005) Lower crustal magma genesis and preservation: a stochastic framework for the evaluation of basalt-crust interaction. J Petrol 46(11):2167-2195

Eiler JM (2001) Oxygen isotope variations of basaltic lavas and upper mantle rocks. Rev Mineral Geochem 43(1):319-364
Elkins-Tanton LT, Grove TL, Donnelly-Nolan J (2001) Hot, shallow mantle melting under the Cascades volcanic arc. Geology 29(7):631-634

Fiske RS, Hopson CA, Waters AC (1963) Geology of Mount Rainier National Park, Washington. USGS Prof Pap 444

Frost BR (1991) Introduction to oxygen fugacity and its petrologic importance. Rev Mineral Geochem 25(1):1-9

Gardner JE, Carey S, Rutherford MJ, Sigurdsson H (1995a) Petrologic diversity in Mount St. Helens dacites during the last 4,000 years: implications for magma mixing. Contrib Mineral Petrol 119:224-238

Gardner JE, Rutherford M, Carey S, Sigurdsson H (1995b) Experimental constraints on pre-eruptive water contents and changing magma storage prior to explosive eruptions of Mount St Helens volcano. Bull Volcanol 57(1):1-17

Gill JB (1981) Orogenic andesites and plate tectonics. Springer, Berlin

Grove T, Parman S, Bowring S, Price R, Baker M (2002) The role of an $\mathrm{H} 2 \mathrm{O}$-rich fluid component in the generation of primitive basaltic andesites and andesites from the Mt. Shasta region, N California. Contrib Mineral Petrol 142(4):375-396

Guillong M, Meier D, Allan M, Heinrich C, Yardley B (2008) SILLS: A MATLAB-based program for the reduction of laser ablation ICP-MS data of homogeneous materials and inclusions. Mineral Assoc Can Short Course 40:328-333

Halliday AN, Fallick AE, Dickin AP, Mackenzie AB, Stephens WE, Hildreth W (1983) The isotopic and chemical evolution of Mount St. Helens. Earth Planet Sci Lett 63(2):241-256

Hansen S, Schmandt B, Levander A, Kiser E, Vidale J, Abers G, Creager K (2016) Seismic evidence for a cold serpentinized mantle wedge beneath Mount St Helens. Nat Comm 7:13242

Hildreth WS (2007) Quaternary magmatism in the Cascades: Geological perspectives. USGS Prof Pap 1744

Hildreth WS, Fierstein J (1997) Recent eruptions of Mount Adams, Washington Cascades, USA. Bull Volcanol 58(6):472-490

Hopson CA, Melson WG (1990) Compositional trends and eruptive cycles at Mount St. Helens Geosci Can 17:131-141

Irvine TN, Baragar WRA (1971) A guide to the chemical classification of the common volcanic rocks. Can J Earth Sci 8(5):523-548

Jicha BR, Hart GL, Johnson CM, Hildreth W, Beard BL, Shirey SB, Valley JW (2009) Isotopic and trace element constraints on the petrogenesis of lavas from the Mount Adams volcanic field, Washington. Contrib Mineral Petrol 157(2):189-207

Karlstrom L, Dufek J, Manga M (2009) Organization of volcanic plumbing through magmatic lensing by magma chambers and volcanic loads. J Geophys Res 114:B10204

Kelemen PB, Hirth G, Shimizu N, Spiegelman M, Dick HJ (1997) A review of melt migration processes in the adiabatically upwelling mantle beneath oceanic spreading ridges. Phil Trans R Soc Math Phys Eng Sci 355(1723):283-318

Kent AJR, Darr C, Koleszar AM, Salisbury MJ, Cooper KM (2010) Preferential eruption of andesitic magmas through recharge filtering. Nat Geosci 3(9):631-636

Kinzler RJ, Donnelly-Nolan JM, Grove TL (2000) Late Holocene hydrous mafic magmatism at the Paint Pot Crater and Callahan flows, Medicine Lake Volcano, N. California and the influence of $\mathrm{H} 2 \mathrm{O}$ in the generation of silicic magmas. Contrib Mineral Petrol 138(1):1-16

Kiser E, Palomeras I, Levander A, Zelt C, Harder S, Schmandt B, Hansen S, Creager K, Ulberg C (2016) Magma reservoirs from the upper crust to the Moho inferred from high-resolution $\mathrm{Vp}$ and Vs models beneath Mount St. Helens, Washington State, USA. Geology 44(6):411-414

Kiser E, Levander A, Zelt C, Schmandt B, Hansen S (2018) Focusing of melt near the top of the Mount St. Helens (USA) magma reservoir and its relationship to major volcanic eruptions. Geology 46(9):775-778 
Larsen LM, Pedersen AK (2000) Processes in high-Mg, high-T magmas: evidence from olivine, chromite and glass in Palaeogene picrites from West Greenland. J Petrol 41(7):1071-1098

Le Bas MJ, Le Maitre RW, Streckeisen A, Zanettin B, Rocks ISotSoI (1986) A chemical classification of volcanic rocks based on the total alkali-silica diagram. J Petrol 27(3):745-750

Le Voyer M, Rose-Koga EF, Shimizu N, Grove TL, Schiano P (2010) Two contrasting $\mathrm{H}_{2} \mathrm{O}$-rich components in primary melt inclusions from Mount Shasta. J Petrol 51(7):1571-1595

Leeman WP, Smith DR (2018) The role of magma mixing, identification of mafic magma inputs, and structure of the underlying magmatic system at Mount St. Helens. Am Mineral 103(12):1925-1944

Leeman WP, Smith DR, Hildreth W, Palacz Z, Rogers N (1990) Compositional diversity of Late Cenozoic basalts in a transect across the southern Washington Cascades: implications for subduction zone magmatism. J Geophys Res 95(B12):19561-19582

Leeman WP, Tonarini S, Chan LH, Borg LE (2004) Boron and lithium isotopic variations in a hot subduction zone-the southern Washington Cascades. Chem Geol 212(1):101-124

Leeman WP, Lewis JF, Evarts RC, Conrey RM, Streck MJ (2005) Petrologic constraints on the thermal structure of the Cascades arc. $\mathrm{J}$ Volcanol Geotherm Res 140(1-3):67-105

Martin-Short R, Allen RM (2013) Mantle flow geometry through the segmented Juan de Fuca plate. Berkeley Seismological Laboratory

Maurel C, Maurel P (1982) Etude experimentale de l'equilibre $\mathrm{Fe}^{2+}-\mathrm{Fe}^{3+}$ dans les spinelles chromiferes et les liquides silicates basiques coexistants a $1 \mathrm{~atm}$. CR Acad Sci Paris 285:209-215

McCrory PA, Blair JL, Waldhauser F, Oppenheimer DH (2012) Juan de Fuca slab geometry and its relation to Wadati-Benioff zone seismicity. J Geophys Res [Solid Earth] 117:B09306

Miyashiro A (1974) Volcanic rock series in island arcs and active continental margins. Am J Sci 274:321-355

Moore NE, DeBari SM (2012) Mafic magmas from Mount Baker in the northern Cascade arc, Washington: probes into mantle and crustal processes. Contrib Mineral Petrol 163(3):521-546

Muffler L, Clynne M, Calvert A, Champion D (2011) Diverse, discrete, mantle-derived batches of basalt erupted along a short normal fault zone: The Poison Lake chain, southernmost Cascades. Geol Soc Am Bull 123:2177-2200

Mullen EK, McCallum IS (2014) Origin of basalts in a hot subduction setting: petrological and geochemical insights from Mt. Baker, Northern Cascade Arc. J Petrol 55(2):241-281

Mullen EK, Weis D, Marsh NB, Martindale M (2017) Primitive arc magma diversity: New geochemical insights in the Cascade Arc. Chem Geol 448:43-70

Mullineaux DR (1996) Pre-1980 tephra-fall deposits erupted from Mount St Helens, Washington. USGS Prof Pap 1563

Pallister JS, Hoblitt RP, Crandell DR, Mullineaux DR (1992) Mount St. Helens a decade after the 1980 eruptions: magmatic models, chemical cycles, and a revised hazards assessment. Bull Volcanol 54(2):126-146

Pallister JS, Thornber CR, Cashman KV, Clynne MA, Lowers HA, Mandeville CW, Brownfield IK, Meeker GP (2008) Petrology of the 2004-2006 Mount St. Helens lava dome-implications for magmatic plumbing and eruption triggering. In: Sherrod DR, Scott WE, Stauffer PH (eds) A volcano rekindled: the renewed eruption of Mount St Helens, 2004-2006, USGS Prof Pap 1750, pp 647-702

Pallister JS, Clynne MA, Wright HM, Van Eaton AR, Vallance JW, Sherrod DR, Kokelaar BP (2017) Field-trip guide to Mount St. Helens, Washington-An overview of the eruptive history and petrology, tephra deposits, 1980 pyroclastic density current deposits, and the crater. USGS Sci Inv Rep 2917-5022-D

Parsons T, Wells RE, Fisher MA, Flueh E, ten Brink US (1999) Three-dimensional velocity structure of Siletzia and other accreted terranes in the Cascadia forearc of Washington. J Geophys Res [Solid Earth] 104(B8):18015-18039

PetDB (2015) Petrological database of the ocean foor. http://www. earthchem.org/petdb. Accessed July 2015

Pin C, Briot D, Bassin C, Poitrasson F (1994) Concomitant separation of strontium and samarium-neodymium for isotopic analysis in silicate samples, based on specific extraction chromatography. Anal Chim Acta 298(2):209-217

Putirka KD (2005) Igneous thermometers and barometers based on plagioclase + liquid equilibria: Tests of some existing models and new calibrations. Am Mineral 90:336-346

Putirka K (2008) Thermometers and barometers for volcanic systems. Rev Mineral Geochem 69:61-120

Rea J, Wallace PJ, Clynne MA (2012) Pre-eruptive volatile content of mafic magma from the 2.0-1.7 ka Castle Creek eruptive period, Mount St. Helens. In: AGU Fall Meeting 2012 Abstracts, abstract no. V53C-2853

Reiners PW, Hammond PE, McKenna JM, Duncan RA (2000) Young basalts of the central Washington Cascades, flux melting of the mantle, and trace element signatures of primary arc magmas. Contrib Mineral Petrol 138(3):249-264

Rose EF, Shimizu N, Layne GD, Grove TL (2001) Melt production beneath Mt. Shasta from boron data in primitive melt inclusions. Science 293(5528):281-283

Rowe MC, Kent AJ, Nielsen RL (2009) Subduction influence on oxygen fugacity and trace and volatile elements in basalts across the Cascade Volcanic Arc. J Petrol 50(1):61-91

Ruscitto D, Wallace P, Johnson E, Kent A, Bindeman I (2010) Volatile contents of mafic magmas from cinder cones in the Central Oregon High Cascades: Implications for magma formation and mantle conditions in a hot arc. Earth Planet Sci Lett 298(1):153-161

Sas M, Debari SM, Clynne MA, Rusk BG (2017) Using mineral geochemistry to decipher slab, mantle, and crustal input in the generation of high-Mg andesites and basaltic andesites from the northern Cascade Arc. Am Mineral 102(5):948-965

Sauerzapf U, Lattard D, Burchard M, Engelmann R (2008) The titanomagnetite-Ilmenite equilibrium: new experimental data and thermo-oxybarometric application to the crystallization of basic to intermediate rocks. J Petrol 49(6):1161-1185

Scandone R, Malone SD (1985) Magma supply, magma discharge and readjustment of the feeding system of Mount St. Helens during 1980. J Volcanol Geotherm Res 23(3-4):239-262

Schmandt B, Humphreys E (2010) Complex subduction and smallscale convection revealed by body-wave tomography of the western United States upper mantle. Earth Planet Sci Lett 297(3):435-445

Schmidt MW, Poli S (1998) Experimentally based water budgets for dehydrating slabs and consequences for arc magma generation. Earth Planet Sci Lett 163(1-4):361-379

Schmidt ME, Grunder AL, Rowe MC (2008) Segmentation of the Cascade Arc as indicated by $\mathrm{Sr}$ and $\mathrm{Nd}$ isotopic variation among diverse primitive basalts. Earth Planet Sci Lett 266(1):166-181

Scott W, Gardner C, Sherrod D, Tilling R, Lanphere M, Conrey R (1997) Geologic history of Mount Hood Volcano, Oregon: a fieldtrip guidebook. USGS Open-File Rep 97-263

Sisson TW, Grove TL (1993) Experimental investigations of the role of $\mathrm{H} 2 \mathrm{O}$ in calc-alkaline differentiation and subduction zone magmatism. Contrib Mineral Petrol 113(2):143-166

Sisson TW, Layne GD (1993) H2O in basalt and basaltic andesite glass inclusions from four subduction-related volcanoes. Earth Planet Sci Lett 117(3):619-635

Sisson TW, Salters VJM, Larson PB (2014) Petrogenesis of Mount Rainier andesite: Magma flux and geologic controls on the contrasting differentiation styles at stratovolcanoes of the southern Washington Cascades. Geol Soc Am Bull 126(1-2):122-144 
Smith DR (1984) The petrology and geochemistry of High Cascade Volcanics in Southern Washington: Mount St. Helens Volcano and the Indian Heaven basalt field. Rice University

Smith DR, Leeman WP (1993) The origin of Mount St. Helens andesites. J Volcanol Geotherm Res 55(3-4):271-303

Smith DR, Leeman WP (2005) Chromian spinel-olivine phase chemistry and the origin of primitive basalts of the southern Washington Cascades. J Volcanol Geotherm Res 140(1-3):49-66

Spiegelman M, Kelemen PB (2003) Extreme chemical variability as a consequence of channelized melt transport. Geochem Geophys Geosyst 4(7):7

Streck MJ, Leeman WP (2018) Petrology of "Mt. Shasta" high-magnesian andesite (HMA): a product of multi-stage crustal assembly. Am Mineral 103(2):216-240

Sun SS, McDonough WF (1989) Chemical and isotopic systematics of oceanic basalts: implications for mantle composition and processes. Geol Soc Spec Pub 42:313-345

Walowski KJ, Wallace PJ, Clynne MA, Rasmussen DJ, Weis D (2016) Slab melting and magma formation beneath the southern Cascade arc. Earth Planet Sci Lett 446:100-112

Wan Z, Coogan LA, Canil D (2008) Experimental calibration of aluminum partitioning between olivine and spinel as a geothermometer. Am Mineral 93(7):1142-1147
Weaver CS, Grant WC, Shemeta JE (1987) Local crustal extension at Mount St. Helens, Washington. J Geophys Res 92(B10):10170-10178

Wells RE, Weaver CS, Blakely RJ (1998) Fore-arc migration in Cascadia and its neotectonic significance. Geology 26(8):759-762

Wells R, Bukry D, Friedman R, Pyle D, Duncan R, Haeussler P, Wooden J (2014) Geologic history of Siletzia, a large igneous province in the Oregon and Washington Coast Range: correlation to the geomagnetic polarity time scale and implications for a longlived Yellowstone hotspot. Geosphere 10(4):692-719

Williams DA, Kadel SD, Greeley R, Lesher CM, Clynne MA (2004) Erosion by flowing lava: geochemical evidence in the Cave Basalt, Mount St. Helens, Washington. Bull Volcanol 66(2):168-181

Publisher's Note Springer Nature remains neutral with regard to jurisdictional claims in published maps and institutional affiliations. 